Viso - Cadernos de estética aplicada Revista eletrônica de estética

ISSN 1981-4062

$N^{0} 15,2014$

http://www.revistaviso.com.br/

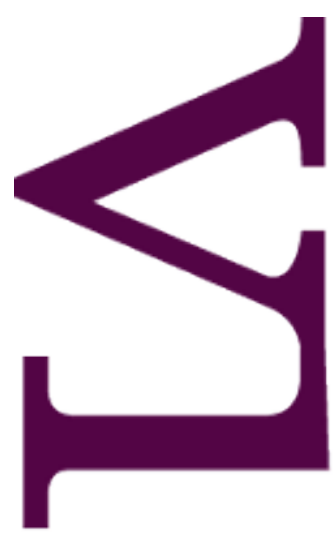

5

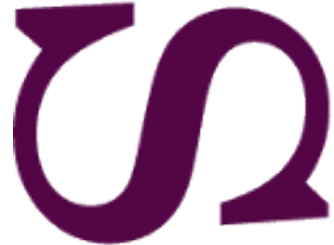

$\varangle$

4

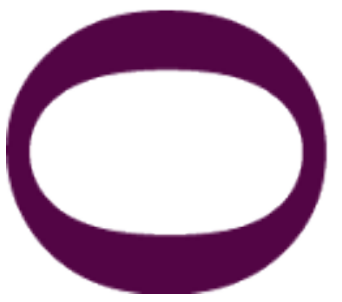

\title{
O paradoxo sublime ou a alforria da arte
} Virgínia Figueiredo 


\section{RESUMO}

\section{O paradoxo sublime ou a alforria da arte}

Neste texto, pretendo analisar a tese principal do ensaio "A verdade sublime" de Philippe Lacoue-Labarthe, a qual poderia ser formulada do seguinte modo: a verdade sublime é o Ereignis, esse é o fundamento a partir do qual se desenvolveu uma dificílima operação que consistiu em modificar a tradição do sublime sempre apresentado negativamente naquilo que Lacoue-Labarthe chamou de "compreensão afirmativa do sublime ou da grande arte". O autor estabelece uma astuciosa aliança entre o que há de mais radical no pensamento de Heidegger e o sublime, tratado de maneira bastante polêmica, como a principal teoria da arte de Kant. Dessa articulação fundamental, pode-se concluir que ele não está apenas à procura de uma "Estética" (sequer de uma "Teoria da Arte") sublime, mas, em busca de algo que é muito mais ambicioso, a saber: de um pensamento do sublime. Portanto, na minha opinião, o ensaio lacouelabarthiano constitui, por um lado, uma referência indispensável não só a quem quer que pretenda estudar a tradição do sublime, mas, por outro, compreender o pensamento heideggeriano sobre a arte e sua tentativa de encontrar uma determinação mais essencial e, sobretudo, ousaria dizer, mais política da arte.

Palavras-chave: Lacoue-Labarthe - Heidegger - Kant - sublime 


\section{ABSTRACT}

\section{The Sublime Paradox or the Enfranchisement of Art}

In this text, I intend to analyze Philippe Lacoue-Labarthe's main thesis in his essay on "The Sublime Truth", that can be taken as the claim that the so-called "sublime truth" is to be thought of as what Heidegger termed Ereignis. This is the foundation on which he attempted a very difficult transformation of the traditional, negatively defined notion of the sublime, into what he called "an affirmative conception of the sublime or great art". Lacoue-Labarthe establishes a very cunning alliance between Heidegger's most radical attempt to think being as Ereignis and Kant's notion of the sublime, interpreted as the key element in Kant's theory of art, properly understood. This shows to my mind that he is looking, under the label of "la pensée du sublime" for something more fundamental than a merely "aesthetic" or "art theoretical" conception of the sublime. For this reason, LacoueLabarthe's essay is not only an indispensable reference for any one interested in the traditional way of thinking the sublime and in Heidegger's thinking about art, but more importantly for any one interested in a more essential—more ontological and surprisingly also more political— determination of art.

Keywords: Lacoue-Labarthe - Heidegger - Kant - sublime 


\section{FIGUEIREDO, V. "O paradoxo sublime ou a alforria da arte". In: Viso: Cadernos de estética aplicada, v. VIII, n. 15 (jan-dez/2014), pp. 127-161.}

DOI: $10.22409 / 1981-4062 / v 15 i / 180$

Aprovado: 15.08.2014. Publicado: 31.01.2015.

(c) 2014 Virgínia Figueiredo. Esse documento é distribuído nos termos da licença Creative Commons Atribuição-NãoComercial 4.0 Internacional (CC-BY-NC), que permite, exceto para fins comerciais, copiar e redistribuir o material em qualquer formato ou meio, bem como remixá-lo, transformá-lo ou criar a partir dele, desde que seja dado o devido crédito e indicada a licença sob a qual ele foi originalmente publicado.

Licença: http://creativecommons.org/licenses/by-nc/4.0/deed.pt_BR

Accepted: 15.08.2014. Published: 31.01.2015.

(c) 2014 Virgínia Figueiredo. This document is distributed under the terms of a Creative Commons Attribution-NonCommercial 4.0 International license (CC-BY-NC) which allows, except for commercial purposes, to copy and redistribute the material in any medium or format and to remix, transform, and build upon the material, provided the original work is properly cited and states its license.

License: http://creativecommons.org/licenses/by-nc/4.0/ 
I.

Talvez jamais tenha sido escrito algo mais essencial sobre o sublime do que o texto de Philippe Lacoue-Labarthe, "A verdade sublime", uma referência, a meu ver, indispensável para qualquer estudo sobre o tema hoje, não só porque ele percorre os vários momentos da história desse conceito, como também porque ele tenta articular o sublime com o conceito que é, dentre todos, irrefutavelmente o mais filosófico: o de "verdade". Como veremos logo a seguir, não é uma noção tradicional de verdade que está em jogo. $E$ quando digo que ela não é "tradicional", pretendo logo excluir a sua implicação com o discurso mais ou menos predominante na nossa época, isto é, o discurso científico. É preciso que se esclareça previamente que a verdade associada à arte não pode estar submetida aos mesmos critérios da verdade científica. Para dizer o mínimo, ela sequer pode obedecer ao princípio básico que rege toda lógica formal/proposicional, que é o princípio da não-contradição, da proibição de se afirmar ao mesmo tempo (e este "ao mesmo tempo" não é uma locução adverbial qualquer... Ela é uma locução temporal que modifica tudo...) que $\mathrm{A}$ é $\mathrm{A} e$ não $\mathrm{A} . .$. Por conseguinte, é importante não se perder de vista que o conceito de verdade, implicado no texto (e já no seu título), é o conceito heideggeriano de verdade, i.e., a alétheia, o desvelamento.

Valho-me das palavras de Benedito Nunes para fazer uma brevíssima elucidação que julguei necessária aqui, nem que seja para mostrar a originalidade da contribuição heideggeriana para o problema da arte e que constitui a tese principal do ensaio " $\mathrm{A}$ origem da obra de arte": a de que a arte é um acontecimento da verdade. ${ }^{2}$ Nunes se pergunta: como não confundir essa tese com as ideias clássica e romântica, que também admitiam a arte como expressão da verdade, racional, no primeiro caso, suprarracional no segundo? No Classicismo, a arte se harmonizava com a verdade na medida em que era imitação da natureza, enquanto no Romantismo o belo artístico foi igualado à verdade. Em que se diferencia a tese heideggeriana dessas duas outras tradicionais? Nunes então responde que em nenhuma delas se falava de um acontecimento da verdade. $^{3}$

E o que significa "acontecimento" (Ereignis)? Mesmo que não esteja propondo percorrer o ensaio de Nunes que leva em conta o argumento de Ser e tempo, assim como as conferências de Heidegger sobre Hölderlin, é preciso chamar atenção para, pelo menos, duas conclusões do seu argumento que elucidam um pouco o sentido dessa difícil noção heideggeriana: a primeira enuncia o caráter resolutamente temporal e histórico que Heidegger atribui à verdade e, por conseguinte, à obra de arte (já que ela é também "acontecimento da verdade"), e a segunda diz respeito ao lugar ao qual pertence a 
verdade como acontecimento, que deixa de ser mais restritamente classificada como conhecimento, dentro de uma disciplina como a epistemologia, mas pertence antes a uma ontologia, na medida em que é um acontecimento da própria história do Ser. Por isso, fiel à estranha "topologia heideggeriana" ${ }^{4}$, Benedito Nunes não hesita em classificar o ensaio "A origem da obra de arte", não como um texto de "estética" ou "filosofia da arte", mas sim como "um capítulo ou fragmento da história do ser". ${ }^{5}$ O Ereignis nos obriga a pensar a História ontologicamente e a Ontologia historicamente.

Voltemos ao ensaio de Lacoue-Labarthe que pretende relacionar, como já se disse aqui, a verdade como alétheia, o "pensamento diretivo de Heidegger" principal teoria da arte de Kant. Com outras palavras, poderíamos dizer que a verdade sublime é o Ereignis. Voltarei a essa hipótese repetidas vezes, pois ela resume e ao mesmo tempo concede, a meu ver, o fundamento a partir do qual se desenvolveu uma difićlima operação que consistiu não apenas em modificar a tradição do sublime sempre apresentado negativamente naquilo que Lacoue-Labarthe chamou de "compreensão afirmativa do sublime ou da grande arte"8, mas também em deslocar o sublime da estética para a ontologia. Tentando explicar melhor: num primeiro gesto, aparentemente ainda estético ou "na própria linguagem da estética [...] mas excedendo secretamente, desde o interior, os limites da estética"9, Lacoue-Labarthe questiona a tradição do sublime como apresentação negativa, apontando a sua origem metafísica. Kant já evidenciara esse "pertencimento" metafísico do sublime, ao afirmar a incorreção de "denominar sublime qualquer objeto", pois, segundo ele, "o verdadeiro sublime não pode estar contido em nenhuma forma sensível". ${ }^{10}$ Mas, muito antes de Kant, desde Longino, o sublime já fazia parte daquela "distinção, herdada do platonismo, entre sensível e suprassensível”"11 que culmina com a fórmula de Lyotard (incluído, portanto, de modo sub-reptício, na mesmíssima tradição metafísica do sublime): a apresentação (disso) que há o inapresentável. ${ }^{12} \mathrm{O}$ gesto seguinte de Lacoue-Labarthe, de apresentar o sublime de maneira afirmativa, pretende numa torção semelhante àquela de Heidegger, desconstruir o sublime ou, pelo menos, como ele mesmo afirma, fazer "desmoronar" o "sublime estético", a fim de apropriá-lo, ouso dizer: ontologicamente. Essa operação depende da possibilidade de examinar (a contrapelo ou, simplesmente, desconstruindo-a) toda a tradição do sublime à luz do que poderia ser chamado de "lógica" da alétheia, i.e., à luz do pensamento de Heidegger.

Essa façanha ou tour de force que consiste em modificar a tradição negativa do sublime em afirmativa, Lacoue-Labarthe a apresenta emblematicamente em Kant, através de dois exemplos de enunciados sublimes que ele pinça da Crítica da faculdade do juízo ${ }^{13}$ : o primeiro, relacionado à tradicional apresentação negativa, é um prescritivo, é a famosa interdição do Antigo Testamento (ou, como está na tradução brasileira, "Código civil dos judeus") da figuração do invisível, do infinito, que Kant introduz justamente através da expressão "talvez, nenhuma passagem mais sublime do que o mandamento: 'Tu não farás qualquer efígie, nem qualquer representação das coisas que estão ou no alto dos céus ou embaixo sobre a terra ou que estão (nas águas) mais baixo que a terra'". ${ }^{14} \mathrm{O}$ 
segundo é um constatativo que está, ao contrário, relacionado ao sublime "afirmativo". É uma passagem extraída de uma nota de rodapé ao §49 sobre o gênio. Trata-se de uma inscrição sobre o templo de Isis (a mãe natureza): "Eu sou tudo o que é, foi e será e nenhum mortal descerrou o meu véu". Essa inscrição foi igualmente introduzida por Kant com um "Talvez jamais tenha sido dito algo mais sublime do que etc.". ${ }^{15}$

O contexto dessa nota de rodapé, esclarece Lacoue-Labarthe, é o de um capítulo fundamental (§49, "Das faculdades do espírito que constituem o gênio") no que toca a possibilidade de uma arte sublime. É preciso deixar claro que as afirmações contidas nas entrelinhas, principalmente: 1) "Analítica do sublime" conteria uma teoria kantiana da arte; 2) O gênio kantiano é o artista sublime; não são de Kant, mas são antes interpretações, sobretudo, dos filósofos franceses contemporâneos "atualizando" a CFJ e colocando o sublime "na moda". ${ }^{16}$ Mas, Lacoue-Labarthe dá um passo além de seus amigos franceses, Derrida, Nancy, Lyotard, Courtine, Déguy, Escoubas (poderia aumentar muito a lista dos autores, na época, debruçados sobre a CFJ), distanciando-se de todos eles, não por qualquer paixão narcisista de destacar-se, ao contrário disso, ele detestava as poses, os estrelismos de toda ordem, mas sim porque, na difícil aliança com o que há de radical no pensamento de Heidegger, ele partiu em busca não somente de uma "Estética" (nem sequer de uma "Teoria da Arte") sublime, mas, em busca de algo que era muito mais ambicioso, a saber: de um pensamento do sublime.

Como estamos em período de Copa do Mundo e Lacoue-Labarthe amava o futebol, a metáfora é legítima. Pois bem, já no pontapé inicial, o seu ensaio projeta para uma posição inédita e inesperada a bola (agora basta de metáforas futebolísticas!) do sublime (tradicionalmente retórico, estético, ou ainda, "apêndice", como vimos em Kant). O lugar para o qual o sublime é imediatamente lançado é o de um pensamento, talvez até o de uma ontologia. Se for ainda "estético", o sublime lacoue-labarthiano é como um dos sentidos possíveis da Estética kantiana: "Transcendental"! Lembrando que "Estética Transcendental" é o título da primeira parte do tratado de "Filosofia Primeira" que é a Crítica da razão pura. Tentando explicar a frase anterior com as próprias palavras de Lacoue-Labarthe: "Se esse gesto de Kant - o de apoderar-se do título de Baumgarten para designar uma filosofia primeira - não tem nada de indiferente, é por causa do sismo que provoca na dita filosofia primeira: na ontologia". ${ }^{17}$ Invertendo (mas, paradoxalmente, levando às últimas consequências) o gesto de Kant, ao tratar como sublime o pensamento de Heidegger (à revelia dele, diga-se de passagem), Lacoue-Labarthe promoveu um verdadeiro terremoto nessa ontologia, a última que foi possível à nossa contemporaneidade, que foi a de Heidegger. O caminho aqui é de mão dupla: se a alétheia forneceu ao filósofo francês uma lógica capaz de pensar (como Heidegger também o exigia) a essência da arte livre da determinação platônica (eidética) do ente, reciprocamente, o sublime, entendido como "trans-luz", i.e., como uma tradução do ekphanéstaton ${ }^{18}$, concedeu à alétheia uma inesperada luz, outro "sistema de iluminação", "totalmente diferente da assunção metafísica do ver e da coerção sem limites do teórico". ${ }^{19}$ 
Assim, o ensaio se dedica a rever toda a tradição do sublime desde Longino, voltando a Platão e Aristóteles, prosseguindo com Kant, Schiller, Hegel, Nietzsche, Freud e Benjamin (talvez tenha esquecido algum filósofo), em busca de aliados capazes de acompanhá-lo na sua difícil tarefa que chamaria, sem muita hesitação, de desestetização da arte, ou, para usar os termos de Heidegger, de "Destruição da Estética". Por outro lado, menos esperado e mais surpreendente, valendo-se de "uma certa interpretação do ekphanéstaton", Lacoue-Labarthe tece uma inédita "história do problema do sublime"20, do pensamento do sublime, através de separações, recortes e seleções, uma vez que não se serve do "sublime em geral"... Pois, como ele mesmo diz, "[há] um certo pensamento do sublime, do excesso do belo, [que] se acomoda facilmente dentro da estética (Burke exemplarmente)" ${ }^{21}$ Como se isso não bastasse, a partir do exemplo da inscrição do templo de Isis, o sublime lacoue-labarthiano ainda promove uma reviravolta no conceito fundamental da Ontologia heideggeriana: a alétheia. No meu modo de entender, em "A verdade sublime", Lacoue-Labarthe faz com a Estética o que Heidegger fizera com a Metafísica Ocidental, i. e., pensou-a a contrapelo. Talvez seja possível formular o problema através da seguinte analogia: se Heidegger cumpriu a tarefa (da "Destruição da Metafísica") a partir da questão do sentido (e depois, da verdade) do Ser; o sublime-ekphanéstaton parece fornecer a Lacoue-Labarthe uma chave para tratar a questão da arte (ou essência da arte) fora da Estética ou, pelo menos, fazendo essa disciplina "desmoronar". ${ }^{22}$

Quero chamar atenção para o fato de ser o nosso autor não somente um leitor de Heidegger, mas muito mais do que isso, um filósofo que considera o pensamento de Heidegger como uma contribuição inelutável para a filosofia e para a tradição do pensamento ocidental como um todo... Muitos leitores e intérpretes de Lacoue-Labarthe, especialmente no Brasil, não estão dispostos a acompanhar esse "pressuposto" (chamemos assim a sua "herança" heideggeriana) a partir do qual Lacoue-Labarthe elabora seu próprio pensamento. Ora, ceifar da mimetologia ou da hiperbológica ${ }^{23}$ sua origem num diálogo com Heidegger é o mesmo que suprimir "as condições de possibilidade" desse pensamento. A alétheia, a questão da desconstrução da metafísica são os pressupostos intrínsecos e essenciais ao pensamento lacoue-labarthiano. Enfim, dou-me o direito de citar a "Apresentação" da revista Terceira Margem, que escrevemos João Camillo Penna e eu mesma e que resume muito bem, pelo menos ainda para mim, a gratidão, a herança e a fidelidade, sentimentos com os quais todo pensamento digno de assim ser chamado está necessariamente envolvido:

Lacoue-Labarthe sempre definiu seu pensamento a partir de um estreito vínculo com Heidegger, a ponto de afirmar, de maneira paradigmática, em 2005 [...], modificando a fórmula habermasiana "pensar contra Heidegger com Heidegger" (que, diga-se passagem, parafraseava o próprio Heidegger falando de Nietzsche), optando, ao invés, por esta outra, bem mais fiel ao seu projeto: pensar 'apesar de Heidegger, mas por causa dele'. A parte final da fórmula, 'por causa dele', não deixa qualquer margem de dúvida a respeito da inegável importância do pensamento heideggeriano para LacoueLabarthe. Enquanto o 'apesar de' aponta, de modo igual e simetricamente incontestável, 
para o problema político de Heidegger, isto é, o "episódio", como se costuma dizer, da adesão de Heidegger ao nazismo, e a ligação umbilical que tem com o todo de sua filosofia. ${ }^{24}$

Antes de se voltar sobre Moisés e Isis, que estão em jogo nos enunciados já citados, Lacoue-Labarthe ainda analisa mais dois exemplos de sublime citados por Kant, nos quais o recurso à metáfora do sol, levantando-se ou se pondo, trata de evidenciar o pertencimento do sublime à tradição metafísica em geral. É necessário seguir de muito perto o argumento lacouelabarthiano, uma vez que ele é sutil e minucioso. Assim, relembrando o ensaio de Derrida, "La mythologie blanche", que diz respeito à recorrente metáfora solar que constitui o discurso metafísico, Lacoue-Labarthe não deixa de concordar com aquele diagnóstico. Ele afirma: "que [o heliotropismo] esteja em operação, tratando-se do sublime, não há nada de surpreendente". ${ }^{25} \mathrm{E}$ por que não é nada surpreendente que no sublime a metáfora solar continue em operação? Precisamente pelo motivo que ele acabara de mencionar: porque, no sublime, trata-se ainda da "apresentação do metafísico enquanto tal". Mas ele "modula", como reconhece Márcio Seligmann-Silva em seu ensaio crítico de Lacoue-Labarthe, com muita ironia, no entanto, ao afirmar a necessidade de "reexaminar de muito perto todo o 'sistema de iluminação' da filosofia". Pois, se, de um lado, o sublime ainda é luz (lembrando mais um exemplo clássico do sublime: "Fiat lux"), sol, iluminação, i. e., heliotrópico como toda metafísica, por outro lado, é possível que outro "sistema de iluminação" seja descoberto, ou esteja encoberto, pelo mesmo sublime encarado do ponto de vista da alétheia heideggeriana. A operação lacoue-labarthiana, como já se disse acima, é muito próxima da de Heidegger e, nesse sentido, essencialmente desconstrutora, pois, no regime da mínima (fototropismo - palavra de Lacoue-Labarthe, ao invés do "heliotropismo" derridiano) diferença, nosso autor alcança revirar o mundo de ponta-cabeça. Porque a principal meta, a partir da qual interessa rever toda a tradição do sublime, foi estabelecida e "orientada", digamos assim, pelo programa heideggeriano de buscar uma "concepção de arte mais arcaica do que a platônica". ${ }^{26}$

Voltemos, finalmente, à análise dos dois exemplos: Moisés e Isis. Lacoue-Labarthe aponta que, apesar de eles não dizerem a mesma coisa, eles têm "certas afinidades". Primeiramente, são enunciados divinos, é um Deus que fala, embora não diretamente. Trata-se de inscrições em Tábuas ou no frontispício de um templo, i.e., a palavra está inscrita. Nos dois casos, ela trata da não-representação do Deus, seja na forma de uma interdição geral de representação, seja na forma de uma declaração de impossibilidade que é apenas aparentemente mais sutil, talvez, seja mesmo mais ameaçadora do que a primeira interdição... Essas afinidades não são puramente formais, elas dizem respeito ao próprio conteúdo do enunciado que diz ser Deus inapresentável:

Estamos, portanto, em termos kantianos (mas também pré-kantianos: desde Longino isso é dito de todas as maneiras), diante da definição canônica do sublime: é sublime toda apresentação do inapresentável ou, mais rigorosamente, para retomar a fórmula de Lyotard, a apresentação (disso) que há o inapresentável. ${ }^{27}$ 
Mas há uma diferença entre os dois enunciados e é por isso que eles não recorrem à mesma metáfora. É verdade que ambos tratam dos limites da apresentação. LacoueLabarthe diz numa frase aguda: "Tout ne se présente pas"28 (enquanto traduzimos num português bem mais frouxo: "Nem tudo se apresenta" ${ }^{29}$ ). Mas se no primeiro exemplo, o da lei mosaica, a apresentação é pensada em termos de figura, imagem, ou em termos bíblicos, efígie, no segundo exemplo, a apresentação é pensada em termos de desvelamento. "E isso", conclui Lacoue-Labarthe, "muda tudo".

Examinemos a análise lacoue-labarthiana que opta claramente pela contraposição dos dois exemplos de sublimidade e verifiquemos o quanto ela está assumindo o recorte heideggeriano que põe de um lado (do lado da subjugação eidética do phainesthai, numa palavra: do lado do "platonismo"), toda estética, senão mesmo toda filosofia; e de outro, Lacoue-Labarthe arrisca a palavra (do lado da apreensão "fântica" da presença), aquilo que ele chama de "grande arte" e que permanece sem reflexão e conceito correspondente. O primeiro exemplo, da lei mosaica, que trata da figuração, ainda estaria subordinado à tradição metafísica de pensar o ente enquanto eidos (segundo Heidegger), já o segundo exemplo que recorre à metáfora do desvelamento abriria um caminho ao encontro entre a estética kantiana do sublime e o pensamento heideggeriano. Concordando com Seligmann, é como um Janus, figura bifronte, que Kant aparece a fim de cumprir a função de estar ao mesmo tempo dentro da tradição pura e simplesmente metafísica do sublime e nessa outra tradição que Lacoue-Labarthe está tentando dificilmente inventar, já fora da moldura metafísica (por conseguinte, da "Estética”), de um sublime 'positivo'.

Mas, a operação é mais complexa do que a mudança de um sinal algébrico ou do que o resultado da aplicação dos ácidos na revelação fotográfica. O caminho do sublime "positivo" que está por ser inteiramente construído, pedra por pedra, inclui a desconstrução, a tarefa crítica. Não se dá um passo à frente sem voltar um (ou mesmo mais do que um) passo atrás. Portanto, progride-se pouco ou quase nada, ou pelo menos, tem-se essa impressão. Mas, ao invés de desanimar, vamos prosseguir. Na sua primeira etapa, o caminho construtivo do sublime (que é, ao mesmo tempo, desconstrutivo ou caminho rumo à desestetização), ao abordar a delimitação heideggeriana da Estética, já tem de se haver, por sua vez, com outras Estéticas, como são, no caso, as de Kant e Hegel. Já aqui se desenrola toda uma política das alianças e das desalianças, da qual a relação com Kant é exemplar. É o próprio Heidegger que sugere a Lacoue-Labarthe encontrar na Estética de Kant um caminho possível, apesar de aparentemente paradoxal, rumo à desestetização. Pelo menos é assim que compreendo a passagem na qual Lacoue-Labarthe afirma que Heidegger teria tratado, por um lado, bastante negativamente, a Crítica da faculdade do juízo como uma estética entre outras, i.e., como uma mera "teoria da subjetividade e do juízo"; por outro lado, ele teria reconhecido tanto em Kant quanto em Schiller uma "exceção", "como se lidos [Kant e Schiller] de certa maneira, tivessem algo a dizer - na própria linguagem da estética que é forçosamente a deles, mas excedendo secretamente, desde o interior, os limites da 
estética - quanto à essência do belo e da arte". ${ }^{30}$

\section{HEIDEGGER E KANT ${ }^{31}$}

Lendo não só o ensaio sobre "A origem da obra de arte", mas também o seminário de Heidegger sobre Nietzsche, Lacoue-Labarthe destaca o capítulo do volume I, "Seis fatos fundamentais extraídos da história da estética", no qual Heidegger, reconhecendo ser "a reflexão sobre a arte e o belo um fenômeno de formação recente, do século XVIII", ainda ali concluía "que a própria coisa que o nome denomina com pertinência [...] era tão velha quanto a própria filosofia". ${ }^{32}$ Isso queria dizer que (assumindo o anacronismo) sempre foi como "Estética" que a filosofia refletiu sobre a arte e sobre o belo. Mas o que significa a "própria coisa" que o nome "Estética" designa? A "própria coisa que o nome 'Estética' designa" é "a maneira de questionar relativamente à arte ou ao belo do ponto de vista daquele que a/o produz e daquele que dela/dele usufrui". ${ }^{33}$ É essa delimitação que orienta a desconstrução em direção a uma interrogação da própria obra que é a essência do ensaio de Heidegger "A origem da obra de arte". ${ }^{34}$ Mas, a radicalidade desse ensaio não reside apenas em ter colocado a obra de arte em questão. Todo o Romantismo Alemão (Schelling e Hegel) já o tinha feito. Como já foi dito aqui, a radicalidade desse ensaio consistiu na afirmação de que a obra de arte é um acontecimento da verdade (das Geschehnis ${ }^{35}$ der Wahrheit). Antecipo agora uma hipótese, cujos elementos para a sua prova ainda não foram dados, e arrisco: numa versão bastante convergente, todavia mais aguda (talvez, o melhor adjetivo fosse: "mais artístico-política") e distinta da de Benedito Nunes ${ }^{36}$, que permanece mais imanente e fiel à letra dos textos de Heidegger, a interpretação de Lacoue-Labarthe, tal como eu a compreendo, dá-se à revelia, a despeito dos escritos de Heidegger e, de modo bastante inédito, trata o conceito-chave de Ereignis, isto é, de acontecimento, à luz da noção de ekphanéstaton, noção essa que serviu de fio condutor a Lacoue-Labarthe para examinar uma certa tradição do sublime, efetivando assim o que ele próprio designou como uma "apreensão fântica da presença" ${ }^{37}$ Assim, o ensaio heideggeriano sobre a "Origem da obra de arte" já exerceria outro modo de pensar a arte, "liberado" de uma "apreensão eidética do ente". No sublime, rejeitado por Heidegger, Lacoue-Labarthe encontraria uma espécie de caminho alternativo ou solução ao problema heideggeriano: o de encontrar um pensamento sobre a arte fora da determinação platônica do ente.

Portanto, examinar o Ereignis à luz do sublime e compreendê-lo como uma "determinação mais arcaica da arte", como acabamos de indicar, é mais uma proeza da ousada interpretação lacoue-labarthiana dos textos de Heidegger sobre a arte, a qual aborda o capítulo do seminário sobre Nietzsche num de seus momentos estratégicos, a saber: quando Heidegger considera (a exemplo do que ocorre na primeira parte das conferências sobre "A origem da obra de arte") a necessidade de desconstruir o par de conceitos, dentre todos, talvez, o mais importante e fundamental para toda Estética: o par matéria e forma. Trata-se de uma passagem do capítulo "Seis fatos fundamentais a partir da história da estética": 
Primeiro nasce o par de conceitos hýle-morphé, matéria-forma. Essa distinção tem sua origem na interpretação platônica do ente em relação ao seu aspecto: eidos-idéa. Aí onde o ente enquanto ente é percebido e distinto dos outros entes quanto a seu aspecto surge a demarcação e a estrutura do ente como delimitação exterior e interior: o que limita é a forma e o limitado, a matéria. Nessas determinações, o que se oferece é aquilo que surge no momento em que a obra de arte é experimentada como aquilo que se mostra: phaínestai segundo seu eidos. O ekphanéstaton, o que se mostra com o maior brilho (Schein) é o belo. Pelo desvio da Idea, a obra de arte se afasta em direção à caracterização do belo como ekphanéstaton. ${ }^{38}$

Lacoue-Labarthe está de pleno acordo com a tese heideggeriana, segundo a qual o par matéria-forma pressupõe a "concepção platônica do ente sob a relação de seu aspecto: eidos, idéa". ${ }^{39} \mathrm{~A}$ afirmação é gravíssima, pois Heidegger faz confluir praticamente toda Estética (qual é a Estética que não utiliza o par matéria e forma?) àquela "predeterminação do ente como eidos". É necessário enfatizar: toda Estética, incluindo a de Nietzsche e Wagner ${ }^{40}$, estaria dentro da moldura da Metafísica, com outras palavras: dentro do "Platonismo"! Tenho quase certeza de que Lacoue-Labarthe concorda com essa drástica afirmação de Heidegger. Mas, aqui, interrompe-se a adesão lacouelabarthiana, que nunca é total. Como se não bastasse a complexidade da operação heideggeriana, tentando desconstruir os conceitos principais da Estética, LacoueLabarthe ainda acrescenta a dificuldade de uma objeção ou, como são as palavras dele: "uma primeira reserva". ${ }^{41}$ Nesse momento, de modo bastante inusual e inesperado, ele se torna mais heideggeriano do que o próprio Heidegger e corrige-o: que o phainesthai tenha sido apreendido como eidos é culpa de Platão, que lega à metafísica essa determinação do ente. Mas, ele continua, "não foi Platão que 'inventou' o phainesthai, esse mostrar-se, aparecer do ente, seu ser luminoso e visível" como Heidegger parece estar dizendo. "Que haja aparecer em geral não depende da apreensão eidética do ente". ${ }^{42}$ É o contrário que acontece, i. e., a apreensão eidética do ente depende de que haja aquele aparecimento com esplendor (ekphanéstaton). E é aí precisamente que Lacoue-Labarthe insere o sublime (que aqui pode ser generalizado para toda e qualquer "Grande Arte") como esse acontecimento que é o desvelamento, momento do aparecer do ente, prévio, anterior ou mesmo liberado da determinação eidética. Esse modo totalmente inédito, sublime, de irrupção da obra de arte, Lacoue-Labarthe denominou-o de "apreensão 'fântica' da presença". ${ }^{43}$ Talvez, numa última tentativa de elucidação desta difícil (concedo) expressão "apreensão fântica da presença", ousaria traduzi-la simplesmente por uma apreensão alethéica da obra de arte.

A operação de "desestetização" consiste, primeiramente, na denúncia de que a Estética jamais questionou a predeterminação metafísica do ente, i. e., jamais questionou sua origem platônica. A Estética que foi o modo desde sempre de refletir sobre a arte e o belo não passa de uma disciplina regional da Metafísica! Nem mesmo Nietzsche, que pretendia reverter o platonismo, se deu conta de que sua proposta de uma "Estética viril" (ou simplesmente sua "Poética") ou oposição entre o Dionisíaco e o Apolíneo ainda estavam submetidos aos mesmos pressupostos tradicionais da "maneira de questionar 
relativamente à arte ou ao belo", isto é, ou "do ponto de vista daquele que a/o produz e daquele que dela/dele usufrui". No segundo passo, é como "Ontologia" que deverá aparecer a reflexão sobre a obra de arte. Lacoue-Labarthe conclui a sua objeção àquela última frase da citação acima, extraída do Seminário sobre Nietzsche - repitamo-la: "Pelo desvio da Idea, a obra de arte se afasta em direção à caracterização do belo como ekphanéstaton" - afirmando que, na verdade, a definição do belo como ekphanéstaton é menos platônica do que... heideggeriana! Lacoue-Labarthe tenta demonstrar sua afirmação, repitamo-la: a de que a definição do belo como ekphanéstaton não é platônica, mas heideggeriana, escrevendo: "Fica difícil sustentar que a definição platônica do belo através do ekphanéstaton seja simplesmente platônica [...] A única coisa que se pode dizer é que, com Platão, introduz-se, definitiva e indubitavelmente, a sobredeterminação eidética do ekphanéstaton". ${ }^{44} \mathrm{E}$ ele continua sua justificativa de interpretação baseado numa passagem, já agora, de "A origem da obra de arte", na qual a definição heideggeriana de belo remete justamente ao ekphanéstaton. Faço uma longa citação:

Esta espécie de proeza (coup de force) poderia muito bem passar despercebida se, na
mesma época, a definição que o próprio Heidegger propõe do belo, levando em conta o
'passo-atrás' na (e diante da) estética inteira, não pudesse, por sua vez, ser relacionada
ao ekphanéstaton. Contrariando todas as expectativas. "Por enquanto, tiro essa
definição de seu contexto que é, por si só e, de resto, muito 'esclarecedor': 'Na obra, diz
Heidegger, é a verdade que vem à obra e não apenas algo verdadeiro (...) É assim que
é iluminado (gelichtet) o ser que se oculta a si mesmo. A luz assim feita agencia seu
aparecer (sein Scheinen) na obra. O brilho do aparecer (das Scheinen) agenciado na
obra é o belo. A beleza é um modo, para a verdade enquanto desvelamento, de
desenrolar a sua essência'. ${ }^{45}$ Isso traz muita luz. Mas o tema da luz e da clareira (Licht,
lichten,Lichtung) é menos decisivo por si só aqui do que a maneira como esse tema
restitui ao Scheinen, ao aparecer, toda sua espessura semântica, que é, como todo
mundo sabe, a mesma do grego phaínesthai: brilhar e luzir, mostrar com brilho,
aparecer, e sobre a qual Heidegger não pára de se apoiar a cada vez que, a propósito
da obra de arte e do belo, evidencia o Scheinen e o trata, a seu modo,
fenomenologicamente. ${ }^{46}$

Aqui, seguindo de perto o seminário de Heidegger sobre Nietzsche, o ensaio lacouelabarthiano passa a analisar o motivo pelo qual a estética kantiana, recusada em todos os outros momentos como uma simples (tal como fora para Hegel) "teoria da subjetividade e do juízo", constituiu um capítulo à parte, destacado e não fazendo parte, portanto, daqueles "Seis momentos fundamentais da história da arte", onde, coerentemente, Heidegger incluíra, além de Hegel, fechando o ciclo, Nietzsche e Wagner... Lacoue-Labarthe examina ainda o fato de Heidegger tomar partido a favor de Kant contra as imprecações de Nietzsche. Já tive oportunidade ${ }^{47}$ de analisar esse terrível quiproquó para a história da Estética e que consistiu no célebre equivoco da interpretação nietzscheana do momento da qualidade (do desinteresse) da "Analítica do belo". Não voltarei a ele. Aqui importa extrair apenas algumas consequências da relação entre Heidegger e Kant ou entre o propósito heideggeriano de encontrar uma determinação mais arcaica do belo e a Estética de Kant: 
1) Naquele jogo das alianças e desalianças, Heidegger é o único filósofo que ousa encontrar uma profunda e inesperada cumplicidade entre Kant e Nietzsche ${ }^{48}$, mesmo à revelia deles, sobretudo, no caso de Nietzsche, que sempre se referiu a Kant com imenso sarcasmo; 2) Kant é quem está mais próximo da determinação do belo em sua essência, quer dizer, da determinação não estética (não eidética) do belo; 3) que apenas o Scheinen, pensado de maneira consequente (quer dizer, de maneira grega), permite um acesso a esta essência. ${ }^{49}$

À pergunta do que Lacoue-Labarthe quer dizer quando lembra que o "belo" kantiano apropriado por Heidegger já não é mais uma categoria "estética" (ou eidética), pode-se responder imediatamente que o "belo" kantiano, ao ser apropriado por Heidegger, já se transformou numa categoria "ontológica".50 Esse deslizamento é absolutamente essencial! É preciso não perder de vista a meta da operação heideggeriana que consiste em retirar a arte (e a obra de arte, por conseguinte) do domínio da Estética (o que significa imediatamente promovê-la ao território do Ser, da ontologia), e assim compreender que talvez estejamos diante de uma determinação mais "arcaica" da arte e do belo. Antes de examinar as (não menos complexas) relações entre Heidegger e Hegel, no que diz respeito à arte, cito mais uma vez o ensaio de Lacoue-Labarthe no ponto no qual sua análise da apropriação heideggeriana do belo kantiano culmina: "Nele [em Kant/vf] aflora uma compreensão do belo mais arcaica (o que não quer dizer mais antiga: ao contrário, enquanto compreensão, está inteiramente por vir) que a compreensão filosófica. E essa compreensão é indicada com uma palavra: Scheinen". ${ }^{1}$

Talvez seja ainda esse (i. e., "ontológico", repito) o sentido de "pensar o Scheinen de maneira consequente (quer dizer, de maneira grega)". Embora não estejam excluídas a ambivalência e certa malícia da expressão "pensar à grega", escolhida a dedo por Lacoue-Labarthe, insisto: é necessário tomá-la de modo ambivalente, ou seja, se Heidegger, por um lado, corria o sério risco de cair naquela idealização grega, caricatura de certo pensamento alemão, cujas consequências políticas Lacoue-Labarthe esteve entre os primeiros a denunciar; por outro lado, não se pode ignorar que a referência determinante do pensamento de Heidegger é a história da filosofia ocidental, e nela, os "gregos" aparecem como os mestres da ontologia, enquanto os "modernos" o são da epistemologia ou da filosofia "esquecida" da questão do ser!

\section{HEIDEGGER E HEGEL}

Embora não pretenda acompanhar tão de perto esta parte do ensaio na qual LacoueLabarthe nos apresenta o confronto entre Heidegger e Hegel, uma pequena escala ou passagem por ela aqui se faz necessária, já que a delimitação heideggeriana da estética, segundo Lacoue-Labarthe, se defrontava com uma grande dificuldade, chamada: Hegel.

Que obras de arte tenham continuado a existir mesmo depois de passado o momento histórico-filosófico de sua morte não constitui, para Heidegger, nenhuma objeção ao 
vaticínio hegeliano. Segundo ele, a existência, ou melhor, a sobrevivência da arte no mundo contemporâneo era somente uma ratificação do axioma hegeliano:

Hegel jamais pretendeu negar essa possibilidade de que outras obras de arte viessem a ser ulteriormente produzidas e apreciadas. O fato de que tais obras isoladas só valham como obras na esfera única do gosto artístico próprio aalgumas camadas sociais, em nada contraria Hegel, mas, precisamente fala em favor dele. Este fato prova que a arte perdeu a potência do absoluto, sua potência absoluta. ${ }^{52}$

Como interpreta Lacoue-Labarthe, diante da arte reduzida à esfera do gosto (da arte que poderíamos chamar justamente de "estética"), a cumplicidade político-filosófica entre Hegel e Heidegger é total. Trata-se de negar à nossa contemporaneidade a possibilidade da "grande-arte", quer dizer, daquela arte "com potência absoluta", capaz de constituir e instaurar a existência de um ser-povo. Na modernidade, Hegel teria dito: a arte deixa de ser religião, e Heidegger: ela deixa de ter uma destinação historial..$^{53}$ Mas se há uma perfeita coerência em Hegel que faz da arte apenas uma das manifestações do absoluto, e não a principal nem culminante, que seria o conceito filosófico, posicionado histórica, lógica e dialeticamente após o momento da arte; essa coerência não existe em Heidegger (Lacoue-Labarthe lembra que se houvesse tal coerência as preleções sobre Hölderlin e os ensaios sobre a obra de arte seriam inquestionável e puramente "estéticos", a exemplo do que ocorre com a "Estética" de Hegel que não recusa de jeito algum sua pertinência, digamos, "metafísica") e é essa falta de coerência que torna difícil a compreensão da operação heideggeriana.

Só assim, explica Lacoue-Labarthe, compreendemos o surpreendente remanejamento ao qual Heidegger submete o axioma ("ingênuo" 54 , qualifica nosso autor) do fim da arte ao qual corresponde o nascimento da estética. Como se, para Heidegger, houvesse dois fins da arte: o primeiro, grego, que marca o próprio início da filosofia, e o segundo, romântico, do pleno desenvolvimento da estética. A Estética de Hegel é entendida como a realização desse segundo momento e Hegel é aquele que detém "a verdade metafísica sobre a arte e o fim da arte". Dessa maneira, Heidegger consegue evitar que se interprete tanto a "reversão do platonismo" nietzscheana quanto as tentativas da "arte total" de Wagner como reconstituições efetivas da "grande arte". Para Heidegger, a estética enquanto metafísica recebe sua formulação final e decisiva com Hegel, mas ele se dá o luxo de incluir naquela elaboração hegeliana mesmo aqueles que vêm depois, como são os casos de Nietzsche e Wagner. A delimitação heideggeriana da Estética não coincide com a hegeliana, porque ela se apoia sobre outro critério, totalmente diferente do hegeliano, que é a "verdade do ente".

Aqui se produz mais um importantíssimo deslocamento do ponto de vista. Se antes havia cumplicidade político-filosófica entre Hegel e Heidegger no anúncio da morte da grande arte, aquela cumplicidade se rompe de modo definitivo, quando se trata de definir propriamente o que seria esta "grande arte" (grega), ou seja, no ponto de vista artísticofilosófico ou simplesmente ontológico. Pois, para Hegel, inspirado pela noção de verdade 
enquanto adaequatio, a "grande arte" grega nada mais significava do que o perfeito acordo entre a matéria e o conteúdo que se queria representar, "apolineamente" emblematizado pela harmonia da estatuária grega. Enquanto que, para Heidegger, "a grande arte" advirá a cada vez que se romper a aliança entre a "apreensão eidética do ente" e o modo como compreendemos a arte. Ou seja, o corte heideggeriano é mais "lógico", digamos assim, por falta de um termo melhor, do que histórico; quero dizer, o critério heideggeriano de definição da "grande arte" como o advento da verdade na obra de arte, ao ocorrer sob a forma do que Heidegger chama de "começo" (Anfang), não é apenas específico da arte grega (lembremos que o ensaio "A origem da obra de arte" concede o mesmo título - de "grande arte" - atribuído ao templo grego à Catedral de Bamberg), mesmo que ela possa constituir um dos exemplos máximos deste critério. Este "começo" implicado com toda "grande arte" é "passado", concordando com Hegel, apenas no caso da arte grega; mas na verdade, ele está mesmo no porvir, ainda não acabou de passar e ocorrerá a cada vez que vigorar outra noção de verdade que não é a platônica, eidética, mas sim, digamos, "alétheica", desvelada. E é precisamente neste sentido que Heidegger não é mais cúmplice de Hegel, no sentido de uma definição ontológica da obra de arte.

Se Hegel detém a verdade metafísica sobre a arte e o fim da arte ${ }^{55}$, talvez, seja a alétheia heideggeriana uma determinação sublime da verdade, e é essa, em resumo, a hipótese que, a meu ver, Lacoue-Labarthe se propõe a examinar. Se se quiser desdobrar o raciocínio analógico que nunca é muito exato: o fim da arte está para Hegel assim como o fim da estética está para Heidegger. Como já vimos aqui, as fronteiras da "Estética" de Heidegger são muito mais amplas do que as de Hegel, pois elas praticamente coincidem com as do país "Metafísica Ocidental"; aliás, como também já foi dito aqui, dentro das fronteiras dessa "meditação a mais compreensiva - porque pensada a partir da metafísica - que o Ocidente possui com respeito à essência da arte" $^{\prime 6}$ que constituem as Preleções sobre a estética para Heidegger, cabem muitos outros filósofos além do próprio Hegel, que está muito bem acomodado nelas e jamais se queixou do título de "Estética". Apesar do inegável respeito que inspiram em Heidegger aquelas Preleções, para ele, Hegel está no fim de um ciclo, cumprindo o papel de enunciar esse fim. Mas o fim que interessa a Heidegger é outro bem diferente do hegeliano, pois é o fim da Estética e da Metafísica e não o fim da Arte como é o caso de Hegel.

Reapresentando o problema: na interpretação heideggeriana, o discurso inaugural da filosofia, que é o discurso platônico, coincide com o momento em que, pela primeira vez, a verdade é apropriada enquanto eidos. Mas o discurso tipicamente filosófico-político da República platônica também se inaugura com a exclusão do poeta trágico, isto é, "da grande arte grega", da pólis. A grande arte grega morreu junto com o nascimento, mais do que da Estética, da própria Filosofia. E dessa demarcação "metafísica" da verdade, da divisão entre o sensível e o suprassensível, nem Nietzsche, nem Wagner escapam, segundo Heidegger. A partir disso, reconstituir a possibilidade de uma grande arte 
significará para Heidegger buscar "uma determinação mais 'arcaica' do ente do que a determinação eidética". É aqui que se articula o "apelo" a Kant, à sua compreensão do belo. Se, por um lado, Heidegger incluíra Kant dentro da circunscrição platônicohegeliana da estética, na medida em que a problemática do belo e do sublime ainda se apresenta, na Crítica da faculdade do juízo, em termos de juízo e imaginação; por outro lado, subtraindo o subjetivismo da Crítica - com a ajuda de Schiller que estava buscando, afinal de contas, kantiana e talvez, aporeticamente, uma teoria objetiva do belo -, Heidegger vai encontrar, principalmente na qualificação do belo kantiano como desinteresse, o "puro Scheinen (que) traduz uma ruptura completa com a apreensão eidética da arte". ${ }^{57}$

\section{VERDADE METAFÍSICA DO SUBLIME x VERDADE SUBLIME DA ARTE}

Se aquela associação entre uma determinação mais "arcaica" (que não quer dizer, como vimos, simplesmente "passada" ou "antiga", mas, ao contrário, em relação ao "começo", é a que ainda está por vir), que rompia com a apreensão eidética da arte e o belo kantiano foi elaborada pelo próprio Heidegger; a associação entre o tema da alétheia, ou seja, da verdade enquanto desvelamento, e o sublime kantiano, é obra de LacoueLabarthe, pois Heidegger jamais se referiu ao sublime. A associação é, no entanto, totalmente legítima, defende-se Lacoue-Labarthe, não apenas por causa do léxico comum entre estes dois temas, mas porque o choque descrito por Heidegger como sendo o acontecimento/advento da verdade na obra de arte não descreve outra coisa senão a experiência sublime. Contra a verdade "metafísica" da estética (e qual seria a verdade metafísica da estética senão o anúncio da morte da arte? ${ }^{58}$ ), Lacoue-Labarthe tenta elaborar, a partir da determinação heideggeriana da verdade enquanto alétheia, uma determinação sublime da arte ou uma verdade sublime da arte. Nesta versão do filósofo francês, o sublime se apresenta como uma categoria no limite da Estética (quase uma Desestética), muito próxima da Ontologia heideggeriana que trata a obra de arte como acontecimento da verdade.

O profundo desprezo de Heidegger pelo sublime não decorre simplesmente da origem tardia desse pensamento "nascido no seio das escolas helenísticas, nem verdadeira nem autenticamente grego, mas contaminado pela latinidade - e mesmo pára-judaico e cristão (ho Hypsos, desde a primeira diáspora na terra grega, significa o Deus da Bíblia: o Muito Alto)". ${ }^{59}$ Lacoue-Labarthe cava mais fundo e aponta que é a estrutura incontestavelmente metafísica do sublime que o torna repulsivo aos olhos de Heidegger; essa estrutura do conceito de sublime que é a distinção metafísica por excelência entre sensível e suprassensível, vigente desde Longino até a versão ético-estética, quer dizer, teológico-estética de Kant. ${ }^{60}$ Não podemos esquecer que o "sublime dinâmico" kantiano era a revelação da faculdade da razão, o que significa a descoberta da vocação humana para a moral que, com outras palavras, quer dizer... o suprassensível. 
Em segundo lugar, mas aqui se desenrola talvez o motivo mais importante, em virtude do qual, aliás, Lacoue-Labarthe compartilha com Heidegger a recusa do sublime, ou pelo menos, do sublime definido negativamente com relação ao belo. Ele continua: "o sublime não oferece nada de mais (motivo do excesso), nem, aliás, nada de menos (motivo do inapresentável) do que, essencialmente, oferece o conceito de belo do qual ele não pára de depender. Não oferece mesmo nada de diferente: é simplesmente um contra-conceito do belo". ${ }^{61}$ Aqui é preciso ter bem claro quem está defendendo o quê, formulemos assim de modo brutal o problema. Pois, se nos passar despercebido que Lacoue-Labarthe está aqui apenas analisando (e eu acrescentaria, "heideggerianamente", o que quer dizer, critica e desconstrutivamente) a tradição (mais predominante, senão a única) do sublime pensado negativamente, podemos nos equivocar totalmente e concluir que LacoueLabarthe "reduziu o sublime ao belo". ${ }^{62}$

Enquanto que o ensaio está tentando elaborar uma versão diametralmente oposta à tradicional e bastante inédita (pois, tanto quanto eu saiba, nenhum outro autor sequer a ensaiou) do sublime... Na sua versão que se pode designar simplesmente de "positiva", não só o sublime não depende do belo, como aqui, muito menos se trata o belo como a superação (Aufhebung) do sublime, como acontece na interpretação hegeliana, a qual, talvez, como considera Lacoue-Labarthe, Heidegger pudesse subscrever sem problemas. De fato, Lacoue-Labarthe encontra uma confirmação "indireta" dessa subscrição, quando Heidegger associa a anti-Estética nietzscheana à definição de sublime por Rilke: "o belo é nada mais que o começo do terrível". ${ }^{63}$ Dependência ou subordinação maior do sublime ao belo impossível! Mas não exageremos a importância dessa passagem Heidegger-Rilke-Nietzsche, pois, lembrando mais uma vez, a noção heideggeriana que está em jogo para Lacoue-Labarthe é a de verdade como alétheia e não a de sublime. Como já foi dito mais de uma vez, não há propriamente conceito heideggeriano de sublime.$^{64} \mathrm{Em}$ contrapartida, é a noção heideggeriana de alétheia que permitirá a Lacoue-Labarthe romper com a interpretação negativa e tradicional do sublime e construir a sua original versão... (escrevo com alguma resistência) "positiva" do sublime.

A outra tese inédita que sustenta Lacoue-Labarthe é a de que Hegel detém a verdade metafísica do sublime. $O$ que isso quer dizer? Aproveitemos para verificar como essa tese está intrinsecamente vinculada à outra, não menos inédita e polêmica, de que o sublime hegeliano, em última instância, sequer pode ser considerado como arte. Infelizmente, não será possível seguir aqui os múltiplos caminhos do ensaio que vai até as Lições sobre a filosofia da religião em busca de uma verdadeira definição do sublime hegeliano. Detendo-nos apenas nos resultados de sua análise perspicaz, acompanhemos a explicação de Lacoue Labarthe:

A razão disso [de a verdade metafísica do sublime culminar com Hegel/vf] é muito simples: desde que a idéia do belo se define pela adequação, figural, entre conteúdo (espiritual) e forma (sensível) - é o Ideal da arte - e desde que a adequação (a "conciliação" como nos diz a Estética) é colocada como a própria necessidade do 
filosofar e do Espírito, o sublime, quer dizer a inadequação da forma ao conteúdo espiritual, é forçosamente pensado como o momento que precede o momento do belo ou da arte propriamente dita [grifo meu]. É por isso que o sublime, que Hegel situa na Arte Simbólica, não é ainda arte (no último caso, é o mesmo que se dá com o momento judeu, da interdição). Ora, é óbvio que essa definição através da adequação (homoíosis) entre o sensível e o supra-sensível e da conformidade espiritual da Gestalt supõe uma determinação eidética do ente. Ela é até, muito explicitamente, a sua verdade. ${ }^{65}$ De fato, é fundado nessa determinação - e somente sobre esse fundo - que Hegel pensa a relação entre o belo e o sublime. ${ }^{66}$

A verdade sublime da arte que Lacoue-Labarthe pretende confrontar com a verdade metafísica do sublime tem de encontrar um novo pressuposto, uma nova concepção do ente, uma determinação não eidética do ente, totalmente alforriada e distinta da adequação. Talvez, dentre as principais tarefas que o pensamento heideggeriano assumiu, esteja a desconstrução da noção de adequação (homoíosis) e conformidade, que afeta não somente o conceito de belo (que só assume importância para Heidegger na medida em que possa ser subtraído da esfera da Estética), mas, antes dele, como ficou estabelecido pelo próprio Heidegger, desde o seu importantíssimo ensaio "Sobre a essência da verdade" ${ }^{67}$, afeta a própria noção de verdade, por conseguinte, a concepção do ente. Talvez caiba dizer algumas palavras sobre esse "luminoso"68 ensaio que constitui, para muitos intérpretes desse pensador, um inquestionável marco, não só para o pensamento heideggeriano (ele é considerado uma passagem entre os dois momento ${ }^{69}$ ), mas para o pensamento contemporâneo como um todo. A reviravolta que Heidegger promove na noção de verdade, arrancando-a do domínio da adaequatio e lançando-a nesse outro "sistema de iluminação"70 que é a alétheia se efetiva através de uma tentativa que é insistente e constante no seu pensamento e que consiste no importante deslocamento de uma perspectiva tradicional do ente em direção ao ser. Então, no caso da verdade, ela deixa de ser proposicional (verdadeiro $x$ falso, erro) adequação da proposição com o ente -, para se tornar desvelamento (alétheia) ou verdade do ser.

\section{CONCLUSÕES PROVISÓRIAS}

O momento da irrupção do Moisés de Miguelangelo no ensaio "A verdade sublime" constitui uma verdadeira "cesura", ruptura "anti-rítmica"71 (se quisermos dramatizar ${ }^{72} \mathrm{e}$ render homenagem ao "homem de teatro" que Lacoue-Labarthe preferia ser em detrimento do "filósofo"), promovendo uma reviravolta, metabolé, nos termos do mais antigo tratado sobre a tragédia que conhecemos. Apresentado pelo ensaio de Freud, o Moisés é a última aparição (refiro-me ainda ao ensaio de Lacoue-Labarthe), digamos assim, do sublime negativo, da "interpretação 'clássica' do sublime"73 que será, definitivamente, interrompida a partir desse momento, cedendo passagem (item 4 do ensaio) à análise do enunciado constatativo de Ísis, exemplo de sublimidade, para dizer resumida mas não muito precisamente, "positiva". O Moisés freudiano constitui assim 
uma espécie de clímax do ensaio lacoue-labartheano, no qual se confrontam (como os pontos mais extremos do sublime) os dois exemplos: do negativo, Moisés, e o afirmativo, Isis, que vai reaparecer na primeira linha do item 4.

Lacoue-Labarthe trata de chamar nossa atenção para 0 paradoxo ${ }^{74}$ (passado em silêncio, no ensaio freudiano sobre Miguelangelo) que constitui esculpir o Moisés. Paradoxo emblemático, na medida em que a estátua é uma figuração do "porta-voz ou do representante do interdito da representação". ${ }^{75}$ Ora, o dilema que afeta o crítico de arte (encarnado por Freud) não o permite defender a representação do Moisés colérico que representaria a verdade do Moisés "bíblico", em detrimento do "artístico" (nesse caso, a obra de arte não seria bem sucedida). Mas esse dilema, que Freud trata de projetar sobre o grande artista que é Miguelangelo ("a causa dessa incerteza, cuja responsabilidade o artista compartilha com o crítico"76), na verdade não parece afetar muito o artista, na medida em que sua representação artística é, finalmente, muito "bem sucedida" (confessa Freud), "o que quer dizer simplesmente bela" (interpreta LacoueLabarthe as palavras de Freud). Ora, ao invés de representar a cólera ("verdadeira", conforme a Bíblia) de Moisés, Miguelangelo preferiu (fez sua opção em favor da beleza) representá-lo no momento seguinte (i.e., seguinte à cólera): da "calma restabelecida". ${ }^{77} \mathrm{~A}$ conclusão de Lacoue-Labarthe foi a de que até Freud estava submetido "à lógica (estética) da adequação, quer dizer, no caso, ao critério do êxito". ${ }^{78}$ Por isso, ele afirmou:

O Moisés [de Miguelangelo] na sua mais nítida oposição à sublimidade judaica (mosaica) é uma homenagem, grandiosa mas bela, restituída à arte segundo sua determinação eidética. Ou, se se preferir, as Tábuas da Lei que Moisés retém in extremis sob seu braço significam, hegelianamente, que a essência do sublime é o belo. ${ }^{79}$

Assim, sob o exemplo do Moisés bíblico, Lacoue-Labarthe classificou toda a tradição dita clássica do sublime, de um certo Longino, passando por Burke, Freud, um certo Kant, Nietzsche e ainda, Rilke; e, no ponto culminante, como vimos, Hegel. Portanto, não resta qualquer dúvida de que, para Lacoue-Labarthe, estão todos (Freud, Hegel e... repetindo a lista, é claro, Miguelangelo) ainda sob o domínio da determinação eidética do ente. Por isso ele não se surpreende com o fato de Freud não se manifestar sobre o paradoxo essa "palavra-chave, desde Longino, e talvez o principal conceito da teoria do sublime"..$^{80}$ Ao contrário, ele tenta explicar esse silêncio de Freud como "sinal, não de uma cegueira ou de um 'esquecimento', mas de um pressentimento: de que aí está em jogo, do ponto de vista da estética, a possibilidade ou a impossibilidade da arte". ${ }^{81}$

Tornado figura, o Moisés emblematiza a aporia da apreensão eidética do sublime, aporia que Lacoue-Labarthe formula assim. Faço aqui mais uma longa citação:

1. Ou Hegel tem razão: a lei mosaica é, na sua própria negatividade, efetivamente sublime, na medida em que pronuncia a essência da sublimidade, a saber, que a apresentação negativa significa a negação da apresentação. Nenhuma arte, no sentido platônico-hegeliano, pode sair daí. Hegel detém a priori e a posteriori a verdade do 
sublime, de Miguelangelo a Schönberg, a figura do Moisés marca simbolicamente a impossibilidade de uma grande arte 'moderna' (quer dizer, na terminologia de Hegel, 'romântica'). E é de resto provavelmente o que destina a arte, em sua aspiração à grande arte, a esgotar-se na apresentação de sua própria impossibilidade, e, por conseguinte, a combater, sob todas as suas formas, a figuralidade.

2. Ou a arte não tem nada a ver essencialmente com a apresentação eidética; e é o que talvez Schiller esteja procurando dificilmente dizer quando fala de 'signos sensíveis' ou de 'apresentação mediata'. Mas se a arte é assim mesmo uma apresentação (e como defini-la de outro modo?), o que ela apresentará de essencialmente diferente da forma ou da figura? Ou, de maneira mais geral: o que poderia ser uma apresentação nãoeidética do ente? O que é que poderia estar em jogo na apresentação, que não seja da ordem do eidos, do aspecto ou da visão?

Esta questão, que diz respeito à apresentação (e não mais à representação, pelo menos no sentido que a filosofia da arte entende), é sem dúvida a questão que, secreta e quase silenciosamente, (res)surge pela primeira vez desde o começo da filosofia com o pensamento de Kant. É justamente a questão que retumba sob a Estética Transcendental e cujo efeito perturbador, com relação ao discurso filosófico, se faz sentir até na problemática da arte. Gostaria de pensar aqui que ela encontra seu emblema na fórmula misteriosa inscrita no templo de Isis: 'Eu sou tudo o que é foi e será e nenhum mortal jamais descerrou meu véu.' Segundo caso, portanto, de sublimidade absoluta. ${ }^{82}$

Visando restringir-me ao fio do argumento que considero fundamental no ensaio, infelizmente, terei de omitir vários desdobramentos, o que seria muito interessante seguir, tais como a relação desnudada por Lacoue-Labarthe entre o Moisés de Freud e o Laocoonte de Schiller e Winckelmann, seu belíssimo comentário à passagem descrita por Hegel do mundo simbólico à emergência do Espírito, o mundo grego, i. e., Édipo, o gênio kantiano e, finalmente (item 6), a longa citação, aliás, sem comentários, de Walter Benjamin $^{83}$ sobre a sublimidade da nudez do corpo humano. Deixo ao leitor o prazer da leitura dessas páginas inesquecíveis. No entanto, não poderei deixar de percorrer as afinidades entre o paradoxo, figura emblemática do sublime de Longino, e a estrutura contraditória da alétheia heideggeriana, pois elas fazem parte do argumento que julgo principal do texto. Encaminho-me, assim, ao desenlace ou às conclusões finais.

\section{A ALÉTHEIA É UMA LÓGICA PARADOXAL}

Parece-me bastante claro, embora não totalmente explicitado no texto de LacoueLabarthe, que a alétheia heideggeriana é mais do que um mero conceito e que ela funciona como uma espécie de lógica, à qual, em minha opinião, Lacoue-Labarthe reconhece logo seu valor especial, sua característica principal, a saber: a de ser uma lógica paradoxal, ou pelo menos, capaz de lidar com o paradoxo. Arrisco dizer que a lógica da alétheia constitui o exemplo da hiperbológica ou, com outras palavras, da lógica trágico-especulativa revelada a Lacoue-Labarthe pela leitura heideggeriana de Hölderlin. Mas é também a "lógica" desse poeta que permite a Heidegger, confrontandose com Hegel, levar a cabo a sua tarefa que consistia em tentar dificilmente pensar fora 
da moldura da dialética hegeliana, fora, portanto, da tríade dialética, não só do momento da síntese, superação da contradição, como também da mediação. O negativo é o elemento responsável pela mediação na dialética.

O que nos permite qualificar essa lógica da alétheia como paradoxal? Primeiramente, o próprio termo "alétheia", traduzido por "desvelamento", contém uma indubitável duplicidade - há ocultação e des-ocultação - sem termo médio. Ao invés disso, Heidegger nos propunha dar um "salto para trás", em direção à origem (Ur-sprung), o que pode ser entendido como um artifício (método?) fenomenológico que mais resiste ao procedimento dialético da mediação. Aqui também não há superação, vitória ou derrota, e muito menos dominação. Há uma dependência mútua entre os termos que, no entanto, se diferenciam. O paradoxo é uma contradição que não será resolvida ou reconciliada e nisso ele se distingue essencialmente da dialética. Talvez, para ser fiel com os termos heideggerianos, tivéssemos de chamar a "lógica da alétheia" simplesmente de "ontologia", lógica do ser ou da diferença ontológica, uma vez que os termos que jamais se equivalem e nunca se assemelham, já o sabemos, são o ser e o ente. O paradoxo é uma diferença irredutível. Cito mais um longo trecho do ensaio de Lacoue-Labarthe que comenta, por sua vez, o texto "A origem da obra de arte", precisamente as passagens nas quais Heidegger se apropriava dos "resultados" do seu próprio ensaio "Sobre a essência da verdade":

Esta proposição - 'A verdade, em sua essência, é a não-verdade' 84 - figura, como todo mundo sabe, na segunda das conferências de Heidegger sobre "A origem da obra de arte". Sobrevém um pouco antes de Heidegger definir a beleza como 'o brilho do aparecer (o Scheinen) agenciado na obra' e como 'um modo, para a verdade enquanto desvelamento, de desenrolar a sua essência.' Nela resume-se a análise que Heidegger conduz sobre a estrutura contraditória da alétheia, e que está destinada a mostrar que 'pertence à essência da verdade enquanto desocultação (Unverborgenheit), a recusa sob a forma da dupla ocultação (Verbergen).' Por 'ocultação', ou 'reserva' [....], Heidegger entende a essência da Lichtung, da claridade ou da clareira, do 'espaço aberto' ou do Aberto, 'onde o ente vem instalar-se'. 'A clareira é (...), ao mesmo tempo, uma ocultação", isso quer dizer: a essência da alétheia é a lèthè (a essência do desvelamento é o velamento); a própria clareira, o desvelamento do ente, não se dá. Ou dito de outra forma: a abertura somente a partir da qual o ente aparece e se apresenta como tal, esta mesma abertura - que, 'pensada a partir do ente', diz Heidegger, é 'mais ente' do que o ente - não se apresenta, quer dizer, não é no modo daquilo que é. A abertura, a clareira, não é nada de ente: 'Este centro de abertura não é circunscrito pelo ente, mas é o próprio centro luminoso que, à maneira do nada que mal conhecemos, descreve o seu círculo em torno de todo ente.

Esse velamento do desvelamento, essa reserva da clareira, diz Heidegger, é dupla: por um lado, ela é instabilidade dissimuladora (Verstellen) do ente, 'desliza na frente do ente', vela-o, fá-lo passar por outro, pelo que não é; eis aí a origem da aparência e do erro. Essa primeira reserva atinge o ente naquilo que ele é (Washeit, quidditas). Mas, por outro lado, e sobretudo - quer dizer, essencialmente - sendo recusa (Versagen), então, ela atinge o ente no seu próprio ser, no seu 'que é' (Dassheit, quodditas): 'O ente 
se recusa a nós, até esse ponto de simplicidade e, aparentemente, de pobreza (Geringste), que só o encontramos mais facilmente, quando, de um ente, não podemos dizer mais do que: ele é. ${ }^{85}$

Essa recusa em que consiste o movimento da alétheia, Lacoue-Labarthe a identifica com a sentença de Ísis "nenhum mortal descerrou o meu véu", chamando-a de "finitude", não como limite do conhecimento, mas ainda assim, kantianamente, como "condição de possibilidade" do desvelamento. Aqui não se fala mais em "apresentação" ou "aparecimento" e, muito menos, em "representação", mas em Ereignis, acontecimento. Para Lacoue-Labarthe, essa lógica temporal da alétheia é tão inovadora que ela seria capaz de reformular de ponta-cabeça a Estética Transcendental. Cito-o mais uma vez:

seria preciso mostrar como todo esse desenvolvimento [o começo da iluminação do iluminado (der Anfang der Lichtung des Gelichteten)] reelabora de ponta a ponta, a partir da consideração da alétheia, a Estética Transcendental. Pois, posto que a clareira não é nada mais do que o aberto, esse espaço puro sem localização ôntica (esse vazio, será dito mais adiante), Heidegger acrescenta logo: 'A desocultação do ente não é jamais um estado dado previamente, mas sempre um acontecimento (Geschehnis). ${ }^{186}$ Quer dizer, a pura temporalidade e, como aparecerá em seguida, a pura historicidade..$^{87}$

De novo, é preciso reiterar a questão: O que é que advém? Do que há advento? Como o acontecimento, que é o desvelamento, é sinalizado? Já entrando na fase final do argumento, gostaria de afirmar em resumo que é na lógica da alétheia que LacoueLabarthe encontra uma possível formulação do que ele próprio chamou de "apreensão fântica da presença". Como se disse um pouco acima, aqui não se trata mais de apresentação ou aparição, mas de acontecimento que "é o estranhamento do ente: das Un-geheuere, sua des-familiarização". ${ }^{88}$

O item 4 foi prática e integralmente dedicado a Heidegger, ao ensaio "A origem da obra de arte", à passagem da questão do quidditas ao quodditas. Essa passagem que Heidegger "verteu na conta do belo", Lacoue-Labarthe verteu na conta do sublime, apropriando-se, digamos assim, da "descrição fenomenológica" que Heidegger faz do Ereignis (ou acontecimento da verdade) como experiência do sublime. $\mathrm{O}$ acontecimento não é neutro e não funciona como uma forma a priori, à espera de um conteúdo empírico, como é o caso das "intuições (kantianas) puras" de tempo e espaço. Talvez seja possível compreender o Ereignis como uma dessas tentativas de apropriação de uma Estética Transcendental totalmente reformulada, uma vez que, diferentemente do tempo e espaço kantianos, pensados enquanto formas puras da sensibilidade, o Ereignis atinge $\mathrm{o}$ ente, desfamiliarizando-o. $\mathrm{E}$ quando o percebemos nesse acontecer, estranhamo-lo como se fosse a primeira vez, como se jamais o tivéssemos percebido.

Ainda que sob a forma de uma recusa (Versagen), o sublime se apresenta, ou, talvez, somente isso: ele é. Mas, aqui, o verbo ser, desobedecendo à regra gramatical, adquire uma forma intransitiva. Deixa de ser um verbo de ligação, como é a sua classificação normal, isto é, verbo que liga um sujeito a um predicativo, que é sempre um adjetivo, 
uma qualidade que é atribuída ao substantivo-sujeito. Aqui, ao invés de ter atributos (e é por isso Heidegger fala em "pobreza" ou "simplicidade"), a obra de arte ("sublime") simplesmente é. O momento de transe e de transport sintetizado por esta metamorfose do verbo Ser - de verbo de ligação em verbo intransitivo constitui a experiência do sublime. A partir daí (do item 4 até o final do ensaio), desenrola-se o "desenlace" dessa nova "história do problema do sublime" que o ensaio de Lacoue-Labarthe nos conta, na qual o começo (concepção negativa de sublime) não vai mais rimar com o fim (da concepção positiva). ${ }^{89}$

Para repercutir essa ideia, é inevitável citar uma importantíssima frase do ensaio sobre a "Origem da obra de arte": "Mas o que existe de mais corriqueiro e habitual do que isto, que o ente seja?" pergunta Heidegger. E ele responde em seguida: "Na obra [de arte], pelo contrário, o inabitual (das Ungewöhnliche) é que ela como tal seja". ${ }^{90}$ Gostaria de traduzir o termo "das Ungewöhnliche" por "extraordinário". Que o ente, no nosso caso, a obra de arte seja, é isso que é extraordinário. A meu ver, essa frase e a sua continuação sobre a singularidade e a gratuidade (Darbringen) ou oferenda que são as marcas do acontecimento (Ereignis) estavam o tempo todo latentes ou "veladas", para permanecer dentro dos limites do léxico da alétheia, no ensaio "A verdade sublime". Latente até esse momento, quando ela irrompe e se manifesta no texto na forma que lhe é própria: de um acontecimento. É essa frase que contém e resume a essência da versão positiva do sublime e que talvez tenha levado Lacoue-Labarthe a dizer que a resposta à questão se existe uma "determinação mais 'arcaica' do ente (Atenção: nem do belo, nem da arte!)", essa resposta estaria no Scheinen, cujo caminho - a partir do item 4 - "positivo" ou "afirmativo" coube a ele construir.

\section{O ESTRANHAMENTO NÃO É UMA APRESENTAÇÃO NEGATIVA}

Na mais próxima circunscrição do ente, sentimo-nos em casa (heimisch). O ente aí é bem conhecido, confiável, familiar (geheuer). No entanto, uma perpétua ocultação atravessa a clareira sob a dupla forma da recusa e dissimulação. O familiar, no fundo, não é familiar; ele des-familiariza. ${ }^{91}$

Interpretando a passagem acima que tenta caracterizar o acontecimento da obra de arte, extraída ainda do mesmo infinito ensaio de Heidegger, Lacoue-Labarthe se pergunta: "Vai se dizer que se trata ainda de uma 'apresentação negativa'”? E ele mesmo responde de modo categórico: “De jeito nenhum"! E, um pouco mais adiante, na mesma página, afirma: "O estranhamento ou a desfamiliarização [outros nomes do sublime lacouelabarthiano] do ente não é nenhuma espécie de 'apresentação negativa'." ${ }^{92}$

A dificuldade dessa passagem é a mesma que ocorre frequentemente no pensamento de Heidegger. Para dizer numa só palavra: a do paradoxo. A exemplo da importante e principal afirmação de que a verdade (Wahrheit) é não-verdade (Unwahrheit) ${ }^{93}$, as aparentes contradições proliferam no texto heideggeriano: o heimisch (doméstico) é unheimlich (estranho-estrangeiro), o geheuer (familiar) é ungeheure (não-familiar), a 
Unverborgenheit (desocultação), Verborgenheit (ocultação). Poderíamos aumentar muito essa lista, mas, para o que nos interessa aqui, ela nos basta. O pensamento paradoxal, adverte-nos o próprio Heidegger, está muito próximo do dialético, mas ele nos previne contra o erro que consistiria reduzir o paradoxo a uma contradição! Heidegger nos alerta: "[A essência da verdade é não-verdade] não quer dizer que a verdade seja, no fundo, falsidade. Ela quer dizer muito menos, numa representação dialética, que a verdade nunca é ela mesma, mas também sempre seu contrário." ${ }^{94}$ Talvez, se quisermos nos manter fiéis a esse pensamento que não quer ser mais metafísico, nem representativo, mas sim meditativo, seja preciso acrescentar uma noção que não aparece aqui, mas no ensaio "Sobre a essência da verdade", que é a de co-pertencimento. Pensar então que verdade e não-verdade se co-pertencem ${ }^{95}$ talvez seja um modo de respeitar o paradoxo, ao invés de, na pressa dialética, querer superá-lo e até suprimi-lo.

O que Ereignis (acontecimento) traz de diferente com relação à dialética é que ele não pretende ser uma lógica que abriga a contradição, mas uma meditação que habita a essência paradoxal de todas as coisas! Aqui nenhuma pretensão de "superação" (como na dialética) e muito menos de "dominação" (pressuposta em toda operação de conhecimento). É por isso que essa "lógica do acontecimento" repele não apenas um termo como o da "representação", mas, como diz Lacoue-Labarthe, nem sequer "a palavra 'apresentação' convém mais". ${ }^{96}$ Aqui o termo insubstituível é o Ereignis. $O$ estranhamento acontece, nós não o representamos e ele nem sequer se apresenta...

Essa perspectiva aberta pelo pensamento heideggeriano que extrapola os limites de uma simples lógica e que eu ousaria chamar de "meditação filosófica" delimita um território da experiência humana que é totalmente distinto do conhecimento e é muito importante para o pensamento da arte. Gostaria de reivindicar esse lugar do meditativo que não se reduz ou simplesmente se diferencia do domínio do conhecimento como sendo o específico da reflexão (nos termos de Kant) ou do "problema da estética", portanto, muito mais próximo do pensar, enquanto uma experiência (atenta àquelas condições, por exemplo) do que do conhecer.

Por que só o termo Ereignis (acontecimento, advento) mostra-se adequado à obra de arte? Arrisco uma resposta: porque somente Ereignis parece não mais negligenciar além do espaço (implícito certamente no termo "apresentação"), o outro elemento intuitivo que participa do fenômeno que toda arte necessariamente é e que, desde Kant, constitui uma das condições de possibilidade da nossa (humana) experiência, isto é, o tempo. Gostaria de sugerir que é o tempo essa intensificação que afeta a presença, e assim compreender por que Lacoue-Labarthe chamou Ereignis de "pura temporalidade" e "pura historicidade". ${ }^{97} \mathrm{O}$ estranhamento ou desfamiliarização que toda obra de arte produz, segundo Heidegger, dá-se no modo de um "golpe" ou "choque" (Stoss) que, apesar do termo, dá-se "sem violência". 
Lacoue-Labarthe insiste que esse choque acontece sem violência, como uma simples "oferenda". Cita, então, mais uma vez o ensaio de Heidegger "A origem da obra de arte":

Quanto mais essencialmente a obra se abre, mais clara [leuchtend] se torna a sua singularidade, definidora do que ela é, ao invés de não ser. Quanto mais essencialmente este choque vem ao aberto, mais estranha [befremdlich] e única se torna a obra. Assim, na produção [Hervorbringen] da obra se encontra esta oferenda [Darbringen]: 'que ela seja'. ${ }^{98}$

Embora aparentemente sem importância, pode-se perceber aqui uma inegável divergência com relação à interpretação que propus no artigo "O sublime explicado às crianças" ${ }^{\prime 99}$ a respeito da violência. Certamente essa maneira sutil e sem violência de o sublime heideggeriano-lacoue-labarthiano acontecer é uma das consequências de sua concepção positiva ou de sua "compreensão 'afirmativa'". Ousaria dizer que, aqui, o sublime foi pensado como uma diferença ontológica. O não-familiar que se descobre no seio da familiaridade acontece sem escândalo, sem aquela grandiosidade que abalava os fenômenos naturais em geral oferecidos como exemplos pela tradição "negativa" e metafísica de interpretação do sublime: tempestades, terremotos, vulcões em erupção etc. Aqui, a sublimidade acontece e altera a nossa rotina, o nosso modo de estar (de existir) no mundo cotidiano. O sublime "transforma nossas relações ordinárias com o mundo e com a terra". ${ }^{100}$

\section{CONCLUSÃO OU A OBRA DE ARTE NÃO É UM ENTE ENTRE OUTROS}

Que me desculpe o leitor se julgo necessária a repetição no momento da conclusão. Retomo as afirmações iniciais desse capítulo apenas para enfatizar a coerência que considero impecável do argumento principal contido no ensaio "A verdade sublime". É forte e bastante fiel a aliança de Lacoue Labarthe com a busca de Heidegger de uma "concepção mais arcaica de arte" e, além disso, a de que o ensaio sobre "A origem da obra de arte", com sua tese de que a obra de arte é um acontecimento da verdade, estaria, diferentemente da imensa produção filosófica a respeito da arte, em condições de nos fornecê-la, i.e., de nos conceder aquela "concepção anterior à predeterminação platônica da arte". Embora a concepção heideggeriana de obra de arte possa parecer-se com a concepção romântica, pois, em ambos os casos, a arte é identificada (e, dignificada, sem dúvida, numa atitude, à primeira vista, anti-platônica) com a verdade, não se pode, de modo algum, reduzir uma concepção à outra. Por quê? Simplesmente porque, antes de relacionar arte e verdade, Heidegger remanejou (é talvez dizer muito pouco) - melhor seria dizer que ele revolucionou - a noção de verdade, ao pensá-la enquanto acontecimento! É necessário então entender a tese inédita da verdade enquanto alétheia como um pressuposto absolutamente essencial à tese que Heidegger herda (digamos assim) dos Românticos e que identifica arte e verdade, só assim compreenderemos por que a ontologização heideggeriana da arte é totalmente distinta do projeto romântico e é capaz de responder sem dificuldade à famosa objeção da qual a linguagem puramente "essencialista"101 dos Românticos não consegue escapar. 
Diferentemente da "Teoria especulativa da Arte" 102 que, a meu ver, nada mais é senão a teoria romântica da Arte, Heidegger estica o pensamento da essência até seu limite máximo, mas mantém-se rigorosamente dentro do limite sem jamais deixar resvalar a essência para dentro do ideal.... Uma coisa é pensar a essência da arte como verdade (mas, no mesmo lance, estabelecer que a verdade é acontecimento, o que, de modo algum, se confunde com um modelo, menos ainda com um ideal ou qualquer coisa que o valha, a desempenhar o papel de um critério que serve de regra, a partir do qual podemos medir e avaliar todo o resto); outra coisa, bem distinta, é identificar a arte com uma verdade, satisfazendo-nos com a definição que nos é dada pela tradição filosófica ocidental e que significa simplesmente que a verdade é um critério transcendente a priori que nos permite separar não somente (como em Kant, só os juízos determinantes) o verdadeiro do falso (motivação cognitiva), o bom do mau (motivação moral) mas também o belo do não-belo (feio ou sublime)... O que, nos termos de Schaeffer, simplesmente "curto-circuita"103 o velho Kant, para quem os juízos estéticos (tanto os do belo quanto os do sublime) eram reflexionantes. Estabelecer uma sintonia aqui entre Kant e Heidegger é totalmente legítimo! O Ereignis como os juízos estéticos não tem ideal nenhum. Ele também não tem qualquer regra, lei ou conceito garantindo-lhe um determinado caminho certo e seguro... Ele é perigoso, como reconheceu Zeljko Loparic. ${ }^{104}$

Estranhamente então, podemos concluir que, apesar de Heidegger ontologizar a arte, e a ontologia heideggeriana ser descrita numa linguagem muito próxima da "essência", jamais poderíamos dizer que o ser para Heidegger é uma... essência! Estaríamos inteiramente equivocados! O ser para Heidegger também não é conceito, nem muito menos ideal. Ele acontece, dá-se (es gibt) a cada vez como diferença do ente. Ele é nada sem $\mathrm{N}$ maiúsculo, claro!

Lamentando não haver mais tempo nem espaço (abusaria da boa vontade dos queridos editores desta Revista) para percorrer o item 5 do ensaio, dedicado ao pensamento "antigo" do sublime (Longino e Aristóteles), passo à conclusão imitando o final do ensaio "A verdade sublime", que culmina com a citação de alguns parágrafos do texto sobre As afinidades eletivas de Walter Benjamin. Assim, ofereço a vocês a última longa citação desse mesmo ensaio que tentei comentar ao longo dessas páginas. Nestes importantes parágrafos, Lacoue-Labarthe justifica, a meu ver, de modo bastante convincente a sua tese, que resumida em pouquíssimas palavras seria a de que o ensaio de Heidegger, "A origem da obra de arte", descreve nada mais nada menos do que "a própria experiência do sublime". E mais do que isso, contrariando toda tradição anterior que sempre apresentou o sublime negativamente, a experiência descrita no ensaio heideggeriano nos proporia uma nova e inédita perspectiva de abordagem do sublime, "[n]uma profundidade sem dúvida desconhecida até ele". Repetindo pela última vez, essa perspectiva seria precisamente "afirmativa", como são os próprios termos do nosso autor. 
Desfamiliarização, desterro e desconcerto, choque, simplicidade, escape ou retraimento, retenção: tudo isso, reconheceu-se, é o próprio léxico do sublime (como fica patente com das Ungeheuere) ou sua transcrição no idioma heideggeriano. Mas claro que não se trata aqui simplesmente de uma questão de léxico, ainda que não se possa dizer que Heidegger seja inocente em matéria de tradição lexical. O que esse texto ["A origem da obra de arte"] descreve, a seu modo e numa profundidade desconhecida até então, é a própria experiência do sublime. Quer dizer, muito precisamente, o que, em outro lugar, a propósito da angústia e especialmente do ser-para-a-morte, Heidegger atribui ao comportamento ek-stático do Dasein e da existência. O choque que a obra produz, quer dizer, o estranhamento do ente é um êxtase ou um arrebatamento desse tipo. É a 'precipitação para fora de si', como diz Burke, a qual, de Longino a Boileau e de Fénelon a Kant, foi descrita como a emoção ou o afeto propriamente sublime - com a condição de, diria Heidegger, entender esse pathos no seu sentido o mais estrito.

Ora, o que advém nessa experiência ou nessa prova? Acontece que se apresenta, quer dizer aparece, diretamente, um ente que 'estranha' a totalidade do ente e, segundo sua irrupção ou irradiação próprias, que haja ente e não nada. A obra é este ente absolutamente paradoxal (este 'ser do ente' ['ser sendo'/vf], como diz A Introdução à metafísica ${ }^{105}$ ) que nadifica [né-antise] o ente a fim de fazer aparecer e vir à luz, brilhar ou cintilar, o próprio ser. A obra abre a clareira, o aberto luminoso no qual, como ente, mantém-se, e sobre o fundo (vazio), o fundo sem fundo do qual vem a manifestar-se o ente. A obra apresenta a alétheia, o nada [né-ant] luminoso, mas de uma 'obscura claridade', que 'é' o ser daquilo que é. E é isso a sublimidade.

[...] Mas a obra - e ela compartilha desse privilégio insigne com o Dasein - não é apenas ente. (grifo meu) Ela é abertura disso, de que há ente. Dito de outro modo, a partir do momento em que é a Dasheit do ente que está em jogo, a apresentação como figuração passa para um segundo plano. Anteriormente ao recorte deste ou daquele ente, ou mesmo antes do que se poderia ainda imaginar como o recorte do ente em geral sobre o fundo do nada (mas o nada não é justamente um fundo e o ente em geral não se recorta: só há recorte ôntico), 'há o ente'. É isso, com efeito, que a obra oferece; mas essa oferenda, esse Darbringen, diz Heidegger, é a de um puro aparecer, Scheinen ou phainesthai, da pura epifania do ente como tal. O que é, enquanto é, não se recorta mas brilha e cintila na noite sem noite, no além-noite do nada, que é a própria clareira.

Por isso, no tema da ocultação (réserve) ou da retenção (do retraimento), na acentuação sobre a léthe, não há qualquer negatividade. Por isso, a apreensão 'fântica' do sublime não pode ceder, imediatamente ou a prazo, a qualquer dialetização. Ela não coloca que o sublime é a apresentação disso, que há o inapresentável (quer dizer, se traduzo direito: o ente negativo); ela não postula qualquer 'apresentação negativa'; ela coloca simplesmente que o sublime é a apresentação disso, que há apresentação. De certa forma, trata-se, ainda que eu tenha certa desconfiança com relação a este termo, de uma compreensão 'afirmativa' do sublime, quer dizer, da 'grande arte'. ${ }^{106}$

* Virgínia Figueiredo é professora titular do Departamento de Filosofia da UFMG.

* Peço desculpas ao leitor, pois foi necessário mudar o texto originalmente apresentado na reunião do GT de Estética (maio de 2014), que teve a honra dos comentários aqui publicados de Luiz Camillo Osório e de Bernardo Oliveira, e que se intitulava "Heidegger e a desestetização da arte". O texto já estava prometido para um livro cuja publicação, a princípio, julguei que tardaria o 
suficiente para aguardar este número da Revista Viso. Como, ao contrário do previsto, o livro ameaçou sair logo, resolvi não correr o risco de comprometer a exigência de ineditismo da revista. Propus, então, aos editores, Patrick Pessoa e Vladimir Vieira, a publicação de outro texto sobre tema bastante conexo (Heidegger, Lacoue-Labarthe, ekphanéstaton, desestetização infelizmente, acabo falando sempre da mesma coisa...), com a única diferença de que há, neste, um foco maior sobre o sublime, que não existia no texto anterior. Aproveito para agradecer muito ao Patrick e ao Vladimir, não só por esta bela edição de mais um número da Revista Viso, como pelo modo simpático e sem entraves com o qual aceitaram a minha proposta de mudança. O texto que se segue é uma análise e comentário do importante ensaio de Philippe LacoueLabarthe, "A verdade sublime", que foi traduzido por mim mesma e está no livro A imitação dos modernos, organizado também por nós: João Camillo Penna e eu mesma. Antecipo que, entre outras coisas, vou discutir e contestar a interpretação que Márcio Seligmann-Silva fez dele, em seu artigo intitulado "Verdades sublimes: Lacoue-Labarthe e a tradição do belo sublime" que foi publicado, por sua vez, na Revista Terceira Margem, n. 17 (julho-dezembro de 2007), número organizado, de novo, pelo João Camillo e por mim, por ocasião da morte do autor.

1 LONGINO. Do sublime, XXXVI, 3-4 apud LACOUE-LABARTHE, P. "La vérité sublime". In: NANCY, J.-L. (org.) Du sublime. Paris:. Belin, 1988, pp. 97-147 ; "A verdade sublime". In: $A$ imitação dos modernos. Tradução de Virginia Figueiredo. São Paulo: Paz e Terra, 2000, p. 261.

${ }^{2}$ Cf. HEIDEGGER, M. A origem da obra de arte. Tradução de Maria da Conceição Costa. Lisboa: Edições 70, 2004, p. 30: "A obra de arte abre à sua maneira o ser do ente. Na obra, acontece esta abertura, a saber, o desocultar, ou seja, a verdade do ente. Na obra de arte, a verdade do ente pôs-se em obra na obra. A arte é o pôr-se-em-obra da verdade".

${ }^{3}$ NUNES, B. "Poética do pensamento". In: Artepensamento. São Paulo: Cia. Das Letras, 1994, p. 390.

${ }^{4}$ Sem que possa precisar onde, em qual texto, ou mesmo se numa comunicação oral, asseguro que o termo é lacoue-labarthiano.

${ }^{5}$ NUNES, B. Op. cit., p. 396.

${ }^{6}$ Ibidem, p. 391.

${ }^{7}$ A meu ver, há uma intenção inegavelmente provocadora ou polêmica nessa afirmação: a de que o Sublime é o pensamento estético principal de Kant, visto que o próprio filósofo transcendental tratara o Sublime como um "simples apêndice" (KANT, I., Kritik der Urteilskraft. Akademische Ausgage, v. 5, p. 78). Voltarei a isso depois.

${ }^{8}$ LACOUE-LABARTHE, P. Op. cit., pp. 253-254. Referindo-se ao antagonismo ou à oposição entre a ocultação (léthe) e a desocultação, que sempre está em jogo na lógica da alétheia, LacoueLabarthe defenderá que "a apreensão 'fântica' [voltarei a essa expressão] do sublime não pode ceder [...] a qualquer dialetização. Ela não coloca que o sublime é a apresentação disso, que há o inapresentável [quer dizer, se traduzo direito: o ente negativo]; ela não postula qualquer 'apresentação negativa'; ela coloca simplesmente que o sublime é a apresentação disso, que há apresentação. De certa forma, trata-se, ainda que eu tenha uma certa desconfiança com relação a este termo, de uma compreensão 'afirmativa' do sublime, quer dizer, da 'grande arte'." Grifos meus.

9 Cf. Ibidem, p. 232. Esses são os termos através dos quais Lacoue-Labarthe interpreta a importante apropriação heideggeriana de Kant e Schiller, i. e., como se eles fossem uma exceção dentro do regime estético.

${ }^{10}$ KANT, I. Kritik der Urteilskraft. Akademische Ausgabe, v. 5, pp. 76-77; Crítica da faculdade do juízo. Tradução de Valério Rohden e Antonio Marques. Rio de Janeiro: Forense Universitária, 1993, p. 91. A partir daqui utilizarei a abreviação CFJ ou a denominação "terceira Crítica". Grifos meus.

${ }^{11}$ LACOUE-LABARTHE, P. Op. cit., p. 240. 
12 Ibidem, p. 229.

${ }^{13}$ Ao contrário do que afirma Márcio Seligmann-Silva em seu artigo "Verdades sublimes: LacoueLabarthe e a tradição do belo sublime" , p. 97, Lacoue-Labarthe não "apresenta os momentos centrais da teoria do sublime na terceira Crítica de Kant"... Não há ali qualquer pretensão de apresentar sistematicamente (como seria necessário, tratando-se de Kant) a "Analítica do sublime". O percurso traçado por Lacoue-Labarthe não tem nada de um comentário tradicional e ortodoxo do texto kantiano. Além do gênio (artista sublime), quase nada mais nos é dito sobre o sublime propriamente kantiano (matemático, dinâmico, sentimento contraditório, passagem para a moralidade, temas necessariamente presentes na maioria dos comentários da "Analítica do sublime"). Ousaria dizer que Lacoue-Labarthe trata como um pretexto (mas, para que isso? Se ele mesmo diz que as duas passagens que ele pinça na terceira Crítica são apenas exemplos? Ele trata, portanto, apenas como exemplos) tanto a interdição do Antigo Testamento, quanto a inscrição sobre o templo de Isis; este último, aliás, à exceção de Schiller (em seu texto "Do sublime"), tanto quanto saiba, nunca chamou a atenção de nenhum comentador da CFJ. Isso tudo sem mencionar o fato de que o exemplo de Isis encontra-se numa nota de rodapé, i. e., mais marginal ao texto propriamente dito da CFJ impossível! A meu ver, o texto de Lacoue-Labarthe desenvolve a lógica ou a estratégia de um verdadeiro parergo à terceira Crítica. Last but not least, lembro que o texto de Derrida sobre a mesma Crítica chamou-se, não por acaso, "Parergon" ( $L a$ vérité en peinture. Paris: Flammarion, 1978)! Ao invés de "momentos centrais da teoria do sublime na Terceira Crítica de Kant", Lacoue-Labarthe se debruça e realmente apresenta o primeiro momento, da qualidade, da famosa tese kantiana do desinteresse que, como todo mundo sabe, pertence à "Analítica do belo". Além disso, o outro "momento da terceira Crítica" que LacoueLabarthe analisa com o detalhe e a minúcia que lhe são característicos é o da teoria do gênio.

${ }^{14}$ KANT, I. AA 05, p. 124; CFJ, p. 121. Grifos meus.

${ }^{15}$ Ibidem, p. 197; CFJ, p. 162.

${ }^{16}$ NANCY, J. L. "L'offrande sublime”. In: DEGUY, M.; NANCY, J. L. (orgs.). Du sublime. Paris: Belin, 1988, p. 37.

${ }^{17}$ LACOUE-LABARTHE, P. Op. cit., nota 31, p. 271. Tradução ligeiramente modificada.

${ }^{18}$ Ibidem, p. 265: "essa trans-luz (é uma tradução para o ek-phanéstaton) é a estranha claridade do próprio ser".

${ }^{19}$ Ibidem, p. 228.

20 Ibidem, p. 265. Essa novidade do sublime lacoue-labarthiano se deve justamente à sua irreverência (atitude que ele aprendeu com Heidegger) com relação à tradição, pois, se por um lado, ele vai buscar aliados inesperados, como é o caso estridente de Heidegger (que fica muito mal "acomodado" na indumentária sublime); por outro, ele deixa de lado, sem sequer se dar ao trabalho da desconstrução, o caminho mais evidente e comum da tradição do sublime ("Burke exemplarmente").

${ }^{21}$ Ibidem, nota 31, p. 271. Tradução ligeiramente modificada.

${ }^{22}$ Cf. Ibidem, p. 271. O parágrafo daquela mesma nota que estou citando começa assim: "Em suma, não falaria de uma 'recusa' da estética, mas de um desmoronamento da estética: o sublime afunda a estética, tira-Ihe o próprio chão. E acrescentaria: que a estética desmorone, nesse sentido, ao toque do sublime, não vale para o sublime em geral..." Grifos meus.

23 "Mimetologia" e "Hiperbológica" são termos cunhados por Lacoue-Labarthe e que podem, num certo sentido, exprimir o essencial de seu pensamento. Poderíamos definir a mimetologia como o pensamento que Lacoue-Labarthe desenvolveu visando cumprir a tarefa de pensar o impensado de Heidegger. A questão da mimesis (e do sublime, certamente) que obceca a reflexão labarthiana é exemplar daquela fórmula, aliás, heideggeriana: a tarefa do pensamento consiste em "pensar o impensado" dos outros pensadores. Quanto à hiperbológica, ver "O imperativo do pensamento", 
apresentação que fizemos João Camillo Penna e eu mesma ao livro $A$ imitação dos modernos, Op. cit.

${ }^{24}$ PENNA, J. C.; FIGUEIREDO, V. "Apresentação" In: Terceira Margem, . 17, (julho-dezembro, 2007), p. 12.

${ }^{25}$ LACOUE-LABARTHE, P. Op. cit. p. 228.

${ }^{26}$ Cf. Ibidem, p. 234.

${ }^{27}$ Ibidem, p. 229.

${ }^{28}$ LACOUE-LABARTHE, P. "La vérité sublime". Op. cit., p. 101.

${ }^{29}$ LACOUE-LABARTHE, P. "A verdade sublime". Op. cit., p. 229.

${ }^{30}$ Ibidem, p. 232.

${ }^{31}$ Toda essa parte (II) do artigo consiste numa retomada do final do texto apresentado na reunião do GT de Estética em maio de 2014 na UFF.

${ }^{32}$ HEIDEGGER, M. Nietzsche. v. I. Tradução de Marco Antônio Casanova. Rio de Janeiro: Forense Universitária, 2007, apud LACOUE-LABARTHE, P. Op. cit. p. 232. Para fins da presente exposição, manteremos as mesmas traduções dos excertos do Nietzsche citados por Lacoue-Labarthe e que foram feitas, naquela época, por Márcia Cristina Gonçalves, especialmente para aquela edição, lembrando que o livro $A$ imitação dos modernos foi publicado no ano 2000, portanto, muito tempo antes da publicação da tradução para o português de Marco Antônio Casanova do citado Seminário de Heidegger (que é de 2007).

${ }^{33}$ LACOUE-LABARTHE, Op. cit., p. 232.

${ }^{34}$ Ibidem. p. 232.

${ }^{35}$ Cf. nota em Ibidem, p. 273: "Sabe-se que nas edições posteriores deste texto ["A origem da obra de arte/vf], Heidegger destacou explicitamente este Geschehnis como Ereignis".

${ }^{36} \mathrm{Fiel}$ a essas duas notáveis interpretações do pensamento heideggeriano sobre a arte, sinto-me obrigada a esclarecer (pelo menos, tentar esclarecer) a pequena diferença que faz uma grande diferença. Talvez, possamos reduzir o detalhe que faz a diferença da interpretação de LacoueLabarthe como decorrente, de um lado, de sua reflexão constante e infatigável sobre o conceito tão importante na Filosofia da arte: mimesis; e de outro, de sua preocupação não menos constante e infatigável com o problema político de Heidegger. Teríamos de examinar com muito cuidado o conteúdo da afirmação de Benedito Nunes, citada logo no início deste trabalho, de que "a conferência de 1935 [A origem da obra de arte] é, do mesmo modo que 'Hölderlin e a essência da poesia', um capítulo da História do Ser". Na sua imanência, diria mesmo, obediência ao texto heideggeriano, é pouco provável que ela pretenda apontar para o mesmo alvo, a meu ver, decidida e obsessivamente político da leitura lacoue-labarthiana que constatamos ao menos neste texto "A verdade sublime" que estamos seguindo aqui, e, muito mais noutros textos (cito apenas alguns: "A transcendência fin (da) ita na política", "Poética e política", Heidegger - la politique du poème e Poétique de l'histoire).

${ }^{37}$ Lacoue-Labarthe inventa esta palavra "fântica (phantique)" a fim de contrapô-la à "eidética", característica da apreensão determinada pela concepção platônica do ente. Resumidamente, a apreensão fântica da presença nos forneceria outro modo de apreensão do ente, num momento do aparecer talvez "anterior" à "submissão eidética (i.e., como eidos)". Cf. LACOUE-LABARTHE, P. Op. cit., p. 231. Com outras palavras: opondo-se à "apreensão eidética do ente", o filósofo francês defenderá que a "apreensão fântica da presença" opera segundo outra lógica [outro "sistema de iluminação da filosofia" (p. 228)], diversa da platônico-metafísica, que é a lógica da alétheia, sob cuja ótica a obra de arte já apareceria no ensaio sobre "A origem da obra de arte.". Essa lógica não vai revirar de ponta-cabeça somente a concepção platônica do ente (e, portanto, a concepção mimética da arte que dela depende), mas também promoveria uma reviravolta na Estética 
Transcendental (cf. p. 250).

${ }^{38}$ HEIDEGGER, M. Nietzsche, p. 74, apud LACOUE-LABARTHE, P. Op. cit. p. 230.

${ }^{39}$ HEIDEGGER, M. "A origem da obra de arte”. apud LACOUE-LABARTHE, P. Op. cit. p. 233.

40 Nietzsche e Wagner aparecem como um dos "Seis fatos fundamentais a partir da história da estética”, capítulo já citado do Seminário de Heidegger sobre Nietzsche.

${ }^{41}$ LACOUE-LABARTHE, P. Op. cit., p. 230.

42 Ibidem, p. 231. Grifo meu.

${ }^{43}$ Ibidem.

44 Ibidem.

${ }^{45}$ HEIDEGGER, M. "A origem da obra de arte" apud LACOUE-LABARTHE, P. Op. cit., p. 231. A tradução citada aqui é de Maria José Rago Campos. O trecho se encontra no volume 79-80, da Revista Kriterion (jun-jul 1987-88), p. 245. Modifiquei um pouco a tradução, incluindo, aliás, as duas últimas frases (a partir de: "O brilho do aparecer etc."), inexplicavelmente omitidas no texto da tradutora.

${ }^{46}$ LACOUE-LABARTHE, P. Op. cit., pp. 231-232.

47 Permito-me remeter o leitor a meu texto "Kant e a mimese", publicado na Studia Kantiana. Revista da Sociedade Kant Brasileira, v. 3, n. 1 (novembro de 2001), pp. 195- 230.

${ }^{48}$ HEIDEGGER, M. Nietzsche. Op. cit., p. 101: "Se, ao invés de confiar em Schopenhauer, Nietzsche tivesse consultado o próprio Kant, ele teria reconhecido que somente Kant compreendeu o essencial daquilo que ele mesmo a seu modo, gostaria de ver compreendido como o decisivo no belo". Tradução ligeiramente modificada.

${ }^{49}$ LACOUE-LABARTHE, P.Op. cit., p. 233. Grifo meu.

${ }^{50}$ Veremos mais adiante (item $\mathrm{VI}$ ) que esse deslocamento em direção à Ontologia pode significar a simplicidade e a pobreza de um constatativo: que a obra de arte seja! Como se o fato de ser antes de qualquer outro atributo pudesse constituir a experiência do sublime. Voltaremos a isso.

${ }^{51}$ LACOUE-LABARTHE, P.Op. cit., p. 234.

${ }^{52}$ HEIDEGGER, M. Nietzsche apud LACOUE-LABARTHE, P.Op. cit., p. 236.

${ }^{53}$ Ibidem, p. 235.

${ }^{54}$ Cf. Ibidem, p. 237. O pensador chama de "ingênuo" o axioma fundamental sobre o qual repousa toda a Introdução das Preleções sobre estética de Hegel e que consiste em sustentar que "a grande arte é absolutamente anterior à toda 'reflexão' (Besinnung) pensante e conceitual”, i.e., não só a arte não seria pensamento para Hegel, como o pensamento vem sempre depois, é sempre tardio. Enquanto que, para Heidegger, a poesia de Hölderlin, por exemplo, já é indubitavelmente pensamento. Essa constitui uma pequena e abissal diferença entre Heidegger e Hegel!

${ }^{55}$ Ibidem.

${ }^{56}$ HEDEIGGER, M. Nietzsche apud LACOUE-LABARTHE, P. Op. cit., p. 235.

${ }^{57}$ LACOUE-LABARTHE, P. Op. cit., p. 238.

${ }^{58}$ Ver nota 55 acima.

${ }^{59}$ Ibidem, p. 239.

${ }^{60}$ Ibidem, p. 240.

${ }^{61}$ Ibidem. 
${ }^{62}$ SELIGMANN-SILVA, M. Op. cit., p. 102. Trata-se de um total equivoco interpretar o texto "A verdade sublime" como uma "redução do sublime ao belo" como o fez Seligmann-Silva. A citação sobre a qual esse autor se apoia para afirmar a sua tese - repito, a meu ver, completamente equivocada sobre o ensaio de Lacoue-Labarthe - foi arrancada de seu contexto e, com isso, perdeu totalmente o seu sentido. E o contexto no qual Lacoue-Labarthe afirma que "a essência do sublime não é outra coisa senão o belo" é precisamente o contexto do "tratamento hegeliano do sublime" (p. 242) que é como Lacoue-Labarthe anuncia o que vai se desenrolar no parágrafo inteiro (por sua extensão, é impossível citá-lo aqui), deixando bem claro o quanto é para Hegel que o belo supera (hebt auf) o sublime; o quanto é apenas hegelianamente que o sublime se dialetiza e não - atenção! - kantiana, nem heideggeriana, nem lacoue-labarthianamente (pois aqui se trava uma estreita e profunda aliança entre Kant, Heidegger e Lacoue-Labarthe). Nesse último "contexto", formado pelo bloco Kant-Heidegger-Lacoue-Labarthe, o sublime é mantido (e apresentado) na sua trágica contradição, sem jamais ser superado... Das duas, uma, ou as duas: ou os olhos não leram porque passaram muito rapidamente pelas palavras ou simplesmente porque não quiseram ler. Enfim, se as fórmulas são mesmo necessárias para facilitar os resumos e as resenhas, diria, usando outras palavras (as mesmas de Seligmann-Silva, mas no sentido inverso) que são menos precisas para definir esse complexo ensaio, eu diria no máximo que, a meus olhos, ao contrário, o artigo "A verdade sublime" reduz o belo ao sublime! Ou ainda que ele sublima (não no sentido freudiano) o belo. Mas, dizer isso é muito pouco e até infiel com a análise minuciosa, minuciosíssima (e jamais "redutora"!) de Lacoue-Labarthe! Talvez pudesse dizer, por analogia com a relação estabelecida por Heidegger entre a alétheia e a verdade como adequação, que Lacoue-Labarthe pretendeu mostrar, no seu ensaio, o sublime como mais originário do que o belo; que o belo é derivado por relação ao sublime. O leitor que quiser se dar ao trabalho poderá constatar (na página inteira do ensaio, p. 242) que a frase "a essência do sublime não é outra coisa senão o belo" está resumindo numa espécie de conclusão justamente a "interpretação 'clássica' do sublime, inclusive [a de] Burke" (p. 242), contra a qual, dificilmente, Lacoue-Labarthe se insurge, buscando junto com Heidegger (mas também "auxiliado" por outros filósofos que ele recorta, tais como um certo Kant, um certo Schiller, um certo Aristóteles e um certo Longino, por exemplo, a fim de torná-los seus aliados, numa operação em tudo semelhante à de Heidegger com relação à Filosofia Ocidental como um todo), uma outra concepção de arte liberada da eidéticoplatônica.

${ }^{63}$ RILKE, R. M. Elegias de Duíno apud LACOUE-LABARTHE, P. Op. cit., p. 240.

${ }^{64}$ LACOUE-LABARTHE, P. Op. cit., p. 254: "Heidegger verte tudo isso, claro, na conta do belo: o remontar do was ist ao dass ist, de 'o que é o ente' ao 'que seja o ente', significa para ele remontar sua determinação filosófica do belo, eidético-estética, a uma determinação mais original do belo. Ainda aqui este pensamento - propriamente sublime - do sublime, não quer saber nada do sublime". Que Heidegger "não queira saber nada do sublime" não impede que Lacoue-Labarthe, que pensa 'apesar de Heidegger, mas por causa dele', o faça. E mais do que isso, obrigue o pensamento de Heidegger a acolher os mesmos temas (a mimesis, o sublime) que ele repele.

${ }^{65}$ HEGEL apud LACOUE-LABARTHE, P. Op. cit., p. 241.

${ }^{66}$ LACOUE-LABARTHE, P. Op. cit., pp. 240-241.

${ }^{67}$ HEIDEGGER, M. "Sobre a essência da verdade". Tradução de Ernildo Stein. Coleção Os pensadores. São Paulo: Abril Cultural, 1983, pp. 144-145.

${ }^{68} \mathrm{O}$ adjetivo não é de Lacoue-Labarthe, mas sim de Ernildo Stein (Na "Apresentação" que faz à sua tradução, p. 129) que se refere à trajetória do ensaio de Heidegger como sendo uma das mais "luminosas do pensamento contemporâneo."

${ }^{69}$ Cf. STEIN, E. Op. cit., p. 129: "Nele [no ensaio] apontam os primeiros sinais da viravolta (Kehre). Enquanto marco inicial da passagem do primeiro ao segundo Heidegger, tornou-se o necessário ponto de referência..."

${ }^{70}$ LACOUE-LABARTHE, P. Op. cit., p. 228. 
${ }^{71}$ Se quisermos estabelecer uma analogia com o famoso comentário de Hölderlin, poderemos dizer que o momento no qual o Moisés de Miguelangelo aparece no texto de Lacoue-Labarthe coincide exatamente com o instante das palavras de Tirésias nas tragédias sofocleanas Édipo-rei e Antígona, i.e., momento da "cesura", segundo Hölderlin.

${ }^{72}$ Não foi apenas para brincar ou jogar com as palavras que considerei como possível, e talvez mais do que possível, desejável a dramatização (ou a "tragedização") do ensaio lacouelabartheano. Percebi que o submetendo à regra da Poética de Aristóteles poderia conceder ao leitor uma eficiente chave de leitura desse dramaticamente (aqui sim estou jogando com as palavras!) difícil e erudito ensaio. Se o considerarmos segundo a estrutura da tragédia, tal como concebida pelo estagirita, poderemos dividir o ensaio em duas partes (não por acaso, são dois os exemplos de sublime): a primeira, negativa e crítica do sublime como apresentação negativa (indo do item 1 ao final do item 3) e a segunda parte, afirmativa e "construtiva" do sublime (indo do item 4 ao final do item 6).

${ }^{73}$ LACOUE-LABARTHE, P. Op. cit., p. 242.

${ }^{74}$ Ibidem, p. 244.

${ }^{75}$ Ibidem.

${ }^{76}$ FREUD, S. "O Moisés de Miguelangelo" apud LACOUE-LABARTHE, P. Op. cit., p. 245.

${ }^{77}$ Ibidem.

${ }^{78}$ LACOUE-LABARTHE, P. Op. cit.,p. 245.

${ }^{79}$ Ibidem. Grifos meus.

${ }^{80}$ Ibidem, p.244. Longino [Do Sublime, XXXV] aparece na nota de rodapé: "o espantoso [para os homens] é sempre o paradoxo."

${ }^{81}$ Ibidem.

82 Ibidem, p. 246.

${ }^{83}$ Talvez Seligmann-Silva tenha sido levado à sua interpretação equivocada do ensaio de LacoueLabarthe (Cf. nota 63) pela influência dessa longa citação do famoso texto de Walter Benjamin sobre as Afinidades eletivas de Goethe, no qual só se fala em belo e nunca em sublime. Esse texto foi traduzido, aliás, generosamente pelo próprio Márcio Seligmann-Silva, na época da publicação do livro (2000). No entanto, chamando a nossa atenção para uma "inquietante" afinidade, LacoueLabarthe poderia ter demonstrado que Walter Benjamin, exatamente como Heidegger, "verte[u] tudo na conta do belo" (ver nota 65), ao passo que a análise lacoue-labarthiana estava seguindo o fio condutor de conceitos bem diferentes dos estéticos. Para evitar o termo comprometedor "ontológico", diria que a orientação de sua análise foi dada, no mínimo, por conceitos "extraestéticos": Schein-Scheinen e ekphanéstaton.

${ }^{84}$ HEIDEGGER, M. "A origem da obra de arte". Tradução de Maria José Rago Campos. Op. cit., pp. 242-245.

${ }^{85}$ LACOUE-LABARTHE, P.Op. cit., pp. 249-250.

${ }^{86}$ HEIDEGGER, P. "A origem da obra de arte". Op. cit., p. 243 . Ver nota 36 a propósito do termo Geschehnis.

${ }^{87}$ LACOUE-LABARTHE, P. Op. cit., p. 250.

88 Ibidem.

${ }^{89}$ Que a obra de arte (Moisés de Miguelangelo) seja constitui o momento de "cesura", a partir do qual, nas palavras de Hölderlin, o "início e o fim simplesmente não mais rimam." "Observações sobre Édipo". Tradução de Pedro Süssekind. In: Hölderlin \& Beaufret. Rio de Janeiro: Jorge Zahar, 2008, p. 80. 
${ }^{90}$ HEIDEGGER, M. Op. cit., p. 53. Tradução ligeiramente modificada: Was aber ist gewöhnlicher als dieses, dass Seiendes ist? Im Werk dagegen ist dieses, dass es als solches ist, das Ungewöhnliche.

${ }^{91}$ HEIDEGGER, M. “A origem da obra de arte” apud LACOUE-LABARTHE, P. Op. cit., p. 250.

${ }^{92}$ LACOUE-LABARTHE, P. Op. cit., p. 251.

${ }^{93}$ HEIDEGGER, P. "A origem da obra de arte" apud LACOUE-LABARTHE, P. Op. cit.,251. Aliás, Heidegger não se contenta em afirmar que a verdade é não-verdade, mas sim, que a essência da verdade é não-verdade: "a verdade, em sua essência, é não-verdade"!

${ }^{94}$ Ibidem.

${ }^{95}$ HEIDEGGER, M. "Sobre a essência da verdade". Op. cit., p. 139.

${ }^{96}$ LACOUE-LABARTHE, P. Op. cit., p. 251.

${ }^{97}$ Ibidem, p. 250.

98 HEIDEGGER, M. "A origem da obra de arte". Op. cit., p. 120, tradução modificada, apud LACOUE-LABARTHE, P. Op. cit., p. 251.

${ }_{99}^{99}$ FIGUEIREDO, V. Trans/Form/Ação, v. 34 (2011), pp. 35-56.

${ }^{100}$ HEIDEGGER, M. "A origem da obra de arte" apud LACOUE-LABARTHE, P. Op. cit., p. 252.

101 Não há dúvida de que a linguagem do próprio ensaio sobre "A origem da obra de arte" seja também essencialista. Como se isso não bastasse, boa parte da segunda parte do ensaio é uma citação de outro ensaio que, mais uma vez, não por acaso se chama "Sobre a essência da verdade". Assim, em muitos momentos, a linguagem heideggeriana se aproxima (só sendo a mesma, para quem não está disposto ao esforço da análise ou não tem "a paciência do conceito", como diria o saudoso Lébrun), de maneira indubitável, da linguagem romântica, que é essencialista e idealizadora. De fato, as afinidades não são poucas! Por isso, Lacoue-Labarthe falou de "outro sistema de iluminação". Isso quer dizer que, muito provavelmente, continuamos com a metáfora da luz (o pensamento manterá a sua tarefa de tentar elucidar, esclarecer etc.), mas aqui ela deixa de iluminar os modelos, os ideais, as essências... O que faz muita diferença! Aqui a mimesis é originária como era a lição tantas vezes repetida por Lacoue-Labarthe. Aqui não há mais modelos nem tipos a serem imitados de maneira preguiçosa e reconfortante.

102 SCHAEFFER, J. M. La théorie spéculative de l'Art. Lyon: Le Nouveau Musée/Institut d'Art Contemporain, 1996. Schaeffer formula muito bem essa crucial objeção, mostrando o quanto a concepção romântica da arte, que ele classifica de "especulativa", regride com relação à Crítica da faculdade do juízo de Kant

103 ibidem, p. 19 : "Ora, o Romantismo simplesmente curto-circuitou a Crítica da faculdade do juízo: ele reduziu o Belo ao Verdadeiro e identificou o juízo estético ao juízo determinante ao fundá-lo na conformidade ou não da obra com um critério transcendente colocado de maneira apriorística (a força de revelação ontológica da obra)."

104 LOPARIC, Z., Heidegger réu - Um ensaio sobre a periculosidade da Filosofia. Campinas: Papirus, 1990.

${ }^{105}$ HEIDEGGER, M. [das seiende Sein] apud LACOUE-LABARTHE, P. Op. cit., p. 252.

${ }^{106}$ LACOUE-LABARTHE, P. Op. cit., pp. 252-254. 